\title{
Kırsallığın Seçilmiş Sosyo-demografik Değişkenler Yardımıyla Kümelenmesi ve Zamana Bağlı Değişimi
}

\section{Clustering of Rurality Based on Selected Sosyo-demographic Variables and Their Variations Over Time}

\author{
Seda Özlü, (1) Sinem Dedeoğlu Özkan, (1) Dilek Beyazlı
}

Karadeniz Teknik Üniversitesi Mimarlık Fakültesi, Şehir ve Bölge Planlama Bölümü, Trabzon

ÖZ

Sosyal, ekonomik, fiziksel ve kültürel yönden farklıııları barındıran kırsal alanlar çok bileşenli bir yapıya sahiptir. Bu çok bileşenli yapı yerleşmelerin geleceği ve sürdürülebilirliği açısından büyük önem taşımaktadır. Kırsalığın nüfus yoğunluğu veya tarım gibi tek boyutlu kriterler ile belirlenmesi gerektiği kabulü tümdengelimci bir yaklaşımla genel kabul gören bölgesel sınıflandırma çabalarının temelini oluşturmaktadır. Nüfus yoğunluğu kriterinin kilit değişken olduğu ulus aşırı karşılaştırmalarının aksine ulusal/bölgesel değerlendirmede zamansal ve bağlamsal değerlendirmeyi olanaklı kılan metodolojilerin geliştirilmesi ve politika oluşturmaya girdi sağlayacak bulguların üretilmesi gerekmektedir. Tek değişkenli sınıflamaların yarattığı sınırlılıkların tartışılması sonrasında Türkiye illeri kırsallığının nüfus yoğunluğuna ek olarak seçilmiş sosyo-demografik değişkenler yardımıyla sınıflandırılması amaçlanmıştır. Kırsal bağlamın heterojen yapısı ve çalışmanın nüfus ölçütünün yanı sıra sosyo-demografik veriler ile kırsallığın zamana bağı değişimini ölçme amacı göz önüne alındığında NUTS-3 düzeyinde çok değişkenli bir süreç izlenmiştir. Çalışmanın veri seti Türkiye İstatistik Kurumu'ndan sağlanmış olup; yöntem olarak İki Adımlı Kümeleme Analizi kullanılmıştır. Çalışma sonucunda sosyo-demografik başlıkta ele alınan benzer ve farklı kümelerde yer alan illerin kırsallık durumlarının zamana ve nedenselliğe bağı olan değişimi karşılaştırmalı olarak tartışılarak değerlendirilmiştir. Sonuçlar, istatistiki bölgelerin ve alt bölgelerin benzerlik-farklılıkları konusunda planlama kararlarına girdi oluşturacak ve sosyo-demografik politikaların üretilmesinde yararlı ve yol gösterici olacaktır.

Anahtar sözcükler: İki adımlı kümeleme analizi; kırsallık; sosyo-demografik yapı; Türkiye (NUTS-3).

\section{ABSTRACT}

Rural areas, which have social, economic, physical and cultural differences, have a multi-component structure. This multi-component structure is of great importance for the future and sustainability of settlements. The acceptance that rural areas should be determined by one-dimensional criteria such as population density or agriculture forms the basis of the generally accepted regional classification efforts with a deductive approach. Contrary to transnational comparisons where population density criteria is key variable, methodologies that would allow temporal and contextual national/regional analyses and findings that would serve as input to future policies are required. After discussing the limitations created by univariate classifications, it was aimed to classify the rural areas of Turkey with the help of selected sociodemographic variables in addition to the population density. Considering the heterogeneous structure of the rural context and the purpose of measuring the time-dependent change of rural life with socio-demographic data as well as the population criteria of the study, a multivariate process was followed at the NUTS-3 level. The dataset was obtained from Turkey Statistical Institute data and Two-Step clustering was used. As a result of the study, the change of rural conditions of the provinces in the similar and different clusters, which are discussed in the socio-demographic title, based on time and causality were discussed comparatively. The results will be useful and guiding for statistical regions and sub-regions as input to the planning decision on similarities and differences and in the production of socio-demographic policies.

Keywords: Two-step cluster analysis; rurality; socio-demographic structure; Turkey (NUTS-3).

Geliş tarihi: 14.10.2019 Kabul tarihi: 06.10.2020

Online yayımlanma tarihi: II.02.202I

İletişim: Seda Özlü

e-posta: sedaozlu@ktu.edu.tr 


\section{Kuramsal Çerçeve}

Günümüzde kırsal alanın ne anlama geldiği ve kırsal nüfusun nerede bulunduğu konusunda geniş bir tartışma söz konusudur (Prieto-Lara ve Ocaña-Riola, 2010). Avrupa Mekânsal Planlama Çalışma Programı'nda belirtildiği gibi gerçekte kırsallığın nesnel veya açık bir tanımını oluşturmak imkânsız olarak görünmektedir. Zaman içerisinde "kırsal alan tanımına ihtiyaç duyan politikacıların, bölgesel/yerel kuruluşların ve farklı disiplinlerde yer alan araştırmacıların tanım ve sınıflama çabaları ile kentsel-kırsal tanımı gittikçe daha belirsiz bir hale gelmiştir' (Öğdül, 2010).

Düşük nüfus yoğunluğu, tarım arazilerinin bolluğu ve kentsel yığılmalardan uzaklık insanların tipik olarak kırsal alanlarla ilişkilendirdiği özelliklerdir (Li, vd., 20I5). Başlangıçta, bir kent merkezinin artık bölgesi olarak görülen kırsal bölge ve kırsallık kavramı zamanla daha kapsamlı hale gelerek derinleştirilmiştir (Bogdanov, vd., 2008). Öyle ki; kırsal alanları kentsel olmayan alanlar veya tarımın ve fiziksel peyzajın önemli olduğu alanlar olarak tanımlamak bugünkü karmaşık gerçeğini anlatmakta yetersiz kalmaktadır (Labrianidis, 2006; Gülümser, vd. 20I0).

Kırsallık sosyal, ekonomik, kültürel ve politik yönlerden özellikle de kırsal alanların geleceği açısından büyük önem taşımaktadır (Avrupa Komisyon Raporu; 1999). Ekonomik faaliyetlerin ve nüfusun kentsel alanlara göçü, tarım sektörünün öneminin kaybolması, kırsal alanlardaki çevresel baskıların ve kırsal toplulukların sürdürülebilirliği konusundaki endişelerin artması sonucunda kırsal alanların değişen doğasını tanımlama ve izleme ihtiyacı (Balestrieri, 2014; Harrington ve O'Donoghue; 1998) acil ve daha da önemli bir hale gelmiştir. Yanı sıra kaynak dağııımını optimize etmeye, alanlar arasındaki eşitsizlik konusundaki boşluğu kapatmaya ve en az avantajlı nüfuslar için yaşam standartlarını yükseltmeye yönelik (Ocaña-Riola ve Sánchez-Cantalejo; 2005) politika ve kararlar açııından da kırsalın tanımı önem taşımaktadır.

Kırsallığın erken tanımları, kentsel ve kırsal topluluklar arasındaki içsel farklılıkları vurgulayan sosyolojik teorilere dayanmakta idi (Harrington ve O'Donoghue, 1998; Cloke 1978). Zaman içinde tarımsal ve endüstriyel üretimdeki yenilikler, ulaştırma-iletişim teknolojilerindeki gelişmeler ve iklim değişiklikleri kentsel-kırsal etkileşimler üzerinde güçlü bir etkiye sahip olmuştur (Leeuwen, 2015). Kentsel ve kırsal alanlar arasında yeni fonksiyonel ilişki türleri geliştikçe ve karmaşık hale geldikçe kırsal-kentsel ikilik dualizminin daha az önemli hale geldiği kabul edilmiştir (Bryden, 2002; Jacobs, 1969). Kentsel-kırsal bağlantıların tek yönlü bir değişimin ötesinde karşılıklı bağımlılıkların olduğu karmaşık ve dinamik bir yapı gösterdiği belirtilmiştir (Leeuwen, 20I5). Kentsel-kırsal süreklilik üzerindeki bu odaklanma, kentsel ve kırsal alanlar arasındaki insanların, sermayenin, malların, bilgi ve teknolojinin görünür ve görünmez akışları ile doğrulanmaktadır (Davoudi ve Stead, 2002). Kırsal-kentsel süreklilik teorisine göre; kırsal-kentsel kavramın coğrafi alanları karakterize eden bir ikilik yerine kırsal bir alandan kentsel bir alana geçişin kademeli olarak gerçekleştiğini bu nedenle kırsal ve kentsel olan arasında gerçek bir boşluk olmadığını, kırsal-kentsel geçişte kademeli fakat farklı aşamaların varlığının kabul edilebileceğini iddia etmektedir (Ocaña-Riola, ve Sánchez-Cantalejo, 2005; Blunden vd., 1998).

Yaşanan gelişmeler ile kentsel ve kırsal alanlar arasındaki ayrımın geçmişteki kadar keskin ve alanları birbirinden ayrıştırmanın da kolay bir konu olmadığı anlaşılmıştır (Combes ve Raybold, 2004; Gülümser, vd. 2010). Böylelikle; çeşitlenen ve birbiri ile etkileşim içinde olan kırsal ve kentsel alanlar için üretilecek karar ve politikaları içeren çalışmalarda kentsel-kırsal ayrımı yerine kentsellik ve kırsallık dereceleri tartışılmaya başlanmışıı. Cloke'un (1977), Cloke ve Edwards'ın (1986) İngiltere ve Galler için oluşturduğu dört kademeli "kırsallık endeksi", Cromartie ve Swanson'un (1996) ABD'nin metropolit çekirdeğinin dışındaki alanları tanımladığı dört seviyeli sınıflandırması, Endonezya'daki yerleşimleri sınıflandırma çalışmaları, Kanada kırsalık endeksi ve İspanya'daki küçük alanlar için kırsallık endeksi, Malinen vd. (1994) tarafından Finlandiya için hazırlanan kırsal alan tipolojisi, Gulumser vd.'nin (2009) Türkiye için kırsal alanları tanımlayan ve sınıflandıran çalışması, Long vd.'nin(2009) Çin'de ki kırsallık bileşik endeksi çoklu sınıflama örneklerinden bazılarıdır (Li, vd.; 2015; Prieto-Lara, ve Ocaña-Riola.; 20l0; Hugo vd; 2003; Öğdül, 2010).

Kentsel-kırsal arasındaki ayrım/ilişki, Avrupa'daki bölgesel entegrasyonun önemli başlıklarından biridir (Öğdül, 20l0). Düşük nüfus yoğunluğu ve tarımın yerel ekonomideki önemli rolü ise Avrupa kırsal bölgelerinin ortak olan özelliklerden ikisi olarak tanımlanabilir. OECD ve EUROSTAT gibi uluslararası kuruluşlar nicel kriterlerin sınırlı güvenirliğine rağmen, kırsal bölgelerin tanımlanmasında özellikle bölgeleri, bölgeler arası veya eyaletler arası karşılaştırmada yararlı olduğu için bu kriterleri benimsemektedir (Ballas, vd. 2003).

Ülkeler arasında aynı tür kentsel ve kırsal bölgelerin sosyo-ekonomik yapılarının karşılaştırılmasının faydalı olduğu bilinmektedir. OECD ülkelerinde kentsel ve kırsal alanlar açısından uygun olabilecek bölgesel sınıflandırma çabaları sonucunda oluşan tipoloji 90'lı yılların başında Kırsal Kalkınma Programı'nın bir parçası olarak aralarındaki coğrafi farklılıkları göz önüne alarak üye ülkelerin bölgelerini, ulusal, bölgesel ve yerel olmak üzere üç hiyerarşik coğrafi ayrıntıya bölmek için temel bir kavramsal çerçeve sağlanmıştır (Sotte, 2003; UNECE, vd. 2007; Pizzoli ve Gong, 2007, Gülümser, vd. 2010; $\mathrm{OECD}, 20 \mathrm{II}$ ). Bölgeleri kırsal birimlerde yaşayan nüfusun yüzdesine göre sınıflayan OECD'nin NUTS 5 düzeyindeki ta- 
nımlamasında nüfus yoğunluğu esas alınmakta olup, 150 kişi/ $\mathrm{km}^{2}$ altındaki yerler kırsal olarak adlandırılmaktadır. NUTS 3 düzeyindeki sınıflamaya göre ise; kırsal topluluklarda yaşayan nüfus \%50'den fazla ise 'baskın kırsal', \%।5-50 ise 'önemli ölçüde kırsal', \%।5'ten az ise 'baskın kentsel' bölgeler olarak tanımlanmaktadır (OECD’nin (1994).

$A B$ tarafından geliştirilen kırsal bölgeleri sınıflandırmaya yönelik yaklaşım da nüfus yoğunluğuna göre önerilen bir değerlendirmedir. NUTS 5 düzeyindeki sınıflama, yoğunluğu 100 kişi/ $\mathrm{km}^{2}$ 'den düşük alanları kırsal olarak tanımlamaktadır. NUTS 3 düzeyindeki yerel sınıflamaya göre ise her biri $500 \mathrm{kişi} / \mathrm{km}^{2}$ 'den fazla nüfus yoğunluğuna ve en az 50.000 bölge nüfusuna sahip bitişik belediye grupları 'yoğun nüfuslu bölgeler' olarak adlandırmaktadır. Yoğun nüfuslu bir bölgeye ait olmayan, her biri $100 \mathrm{kişi} / \mathrm{km}^{2}$ den fazla nüfus yoğunluğuna sahip belediye grupları 'orta yoğunluklu bölgeler' olup; bölgenin toplam nüfusu en az 50.000 kişi veya yoğun nüfuslu bir bölgeye bitişik olmalıdır. 'Düşük nüfuslu bölgeler': yoğun nüfuslu veya orta dereceli olarak sınıflandırılmayan belediye gruplarıdır (Boscacci vd., 1999; EUROSTAT, 20I0; Balestrieri, 20I4).

Avrupa Mekânsal Gelişim Perspektifi (ESDP); kentsel-kırsal ortaklıkların gelişimini şiddetle savunan ESDP; kentsel alanların sunduğu fırsatların çoğu zaman kırsal alanlar için tamamlayıc olduğunu, kasaba ve şehirlerin rakip olarak değil ortak olarak görülmesi gerektiğini belirtmektedir (Davoudi ve Stead, 2002). Bu tipolojideki sınıflar ise; büyük metropollerin egemen olduğu bölgeler, kentsel ve kırsal yoğunlukları yüksek olan çok merkezli bölgeler, yüksek kentsel yoğunluklu çok merkezli bölgeler, metropoliten alan etkisi altındaki kırsal alanlar, orta ve küçük kasaba ağları ve uzak kırsal alanlar olarak tanımlanmaktadır (Avrupa Komisyonu; 1999).

ESPON projesi; kırsal alanların hangi dereceye kadar işlevsel olarak kent merkezlerine bağlı olduklarını ortaya koymaktadır. Sınıflandırma, "kırsal" ve "kentsel” bölgelerin birbirlerine olan bağımlılığını gösteren iki ana göstergeye dayanmakta olup; kategoriler yüksek kentsel nüfus, yüksek insan müdahaleleri ile düşük kentsel nüfus, düşük insan müdahaleleri arasında değişmektedir (Bengs ve Schmidt, 2005).

Uluslararası yazın taramasında yer alan çalışmalar ülkemizde de ses bulmuş ve hem ulusal hem de yerel ölçekte kırsallığı ele alan ampirik çalışmalar gerçekleştirilmiştir. DPT (1982) tarafından hazırlanan 'ülke ve bölge çapındaki etkilerine göre bölgelerin sınırları ile özekleri de belirleyen' Türkiye'de Yerleşme Merkezlerinin Kademelenmesi ile DPT'nin (2004) '... ilçelere bağlı kırsal kesimleri de bir bütün olarak değerlendiren' "ilç̧elerin Sosyo-Ekonomik Gelişmişlik Düzeyi Sıralaması” çalışması Türkiye'de ki ilk kırsal sınıflama çalışmaları olarak tanımlanmaktadır. Gülümser vd.,'nin (20l0); seçilmiş kırsal gelişme göstergeleri ile Türkiye'nin kırsal yapısını AB üye ülkeleri ile karşılaştırmalı olarak değerlendirdiği çalışması, Öğdül vd.'nin (2010) NUTS 4 düzeyinde kentsel-kırsal bağlamda bölgelerin çeşitliliğine vurgu yaparak, ülke genelinde kentlilik ve kırsallık derecelerini ortaya koyan çalışması ve TÜBiTAK'ın (20l4) "kentsel-kırsal ayrımının bir tür sorunu değil bir kademelenme sorunu olduğunu” iddia eden "Koruma Odaklı Kırsal Alan Planlaması: Bir Model Önerisi” projesi ulusal yazında kırsal alanı ve kırsallığı ele alan önemli çalışmalardandır.

Geleneksel olarak nüfusun mutlak büyüklüğü, bir alanın kırsal olarak tanımlanmasını sağlayan en yaygın ölçüt olmuştur (Ocaña-Riola, ve Sánchez-Cantalejo, 2005). Makro ölçekli çalışmalarda sıklıkla kullanılmasına karşın (Madu, 20l0) kırsallık gibi karmaşık bir kavramı tek bir değişkenle tanımlamak zordur (Ocaña-Riola, ve Sánchez-Cantalejo, 2005; Prieto-Lara, ve Ocaña-Riola.; 2010). Aynı zamanda nüfus yoğunluğu kırsalda doğru olanı tanımlamada yetersiz veya en azından eksik bir gösterge olarak görünmektedir (Balestrieri, 20l4). Düşük nüfus yoğunlukları her zaman kırsal nüfuslarla ilişkili olmayıp; yüksek nüfus yoğunlukları da her zaman bir kentsel nüfusun varlığına işaret etmemektedir (Labrianidis; 2006). Bu nedenledir ki; kırsal alanların heterojenliğinin bir sonucu olarak, yalnızca nüfus ve/veya tek bir ekonomik faaliyete dayalı kırsal tanımının, alanları veya bölgeleri kırsal olarak tanımlamak için yeterli olmadığını göstermiştir (Madu, 2010). Nüfus yoğunluğuna ek veya alternatif olarak, bölgesel sınıflandırma için birden fazla kriter veya başka değişkenler önerilmektedir (Pizzoli and Gong; 2007). Genel olarak, literatürdeki çeşitli sınıflandırma ve tanım çalışmalarında nüfus yoğunluğu, nüfus artış veya azalış oranı, yerleşim büyüklüğü, yerel ekonomik yapı, erişilebilirlik ve peyzaj vb. gibi değişkenler kırsallık derecesindeki farklılıkları ölçmek için türetilmiştir (Ballas vd., 2003; Baum vd, 2004; Bryden, 2002; IIbery, 1998; Labrianidis, 2004; Li, vd., 2015). Ayrıca; Avrupa Komisyonu (2007-2013) tarafından demografik özellikler, istihdam, tarım ve turizm konuları dâhil ekonomik yapılar, beşeri sermaye, ulaştırma ve telekomünikasyon altyapısı ve mekânsal karakteristikleri yansıtan değişkenler kilit sosyal, ekonomik ve demografik verilerin izlenmesi ve değerlendirilmesi yoluyla kırsal alanların yapısını ve işleyişini yakalamaya çalışmaktadır (Bogdanov, 2008).

Özetle; kentsel-kırsal sınıflandırmalar kırsal ve kentsel alanlar arasındaki fonksiyonel ilişkilere dayanan basit yoğunluk yaklaşımlarından daha karmaşık sınıflandırmalara doğru gelişmiştir (Bryden, 2002). Kentsel ve kırsal tanımının belirsizliği, çeşitlenen ve birbiri ile etkileşim içinde olan kentsel-kırsal alanların tek değişken ile yapılan tanımlarının sınırlılıkları çalışmalarda daha karmaşık metodolojilerin ve çoklu değişkenlerin kullanılmasını gerektirmiştir. Bu bağlamda yurt içi/yurt dışı yazında kırsal alan ve kırsallığı tanımlamada ve sınıflamada kullanılan sosyo-demografik değişkenler Tablo I'de verilmiştir. 


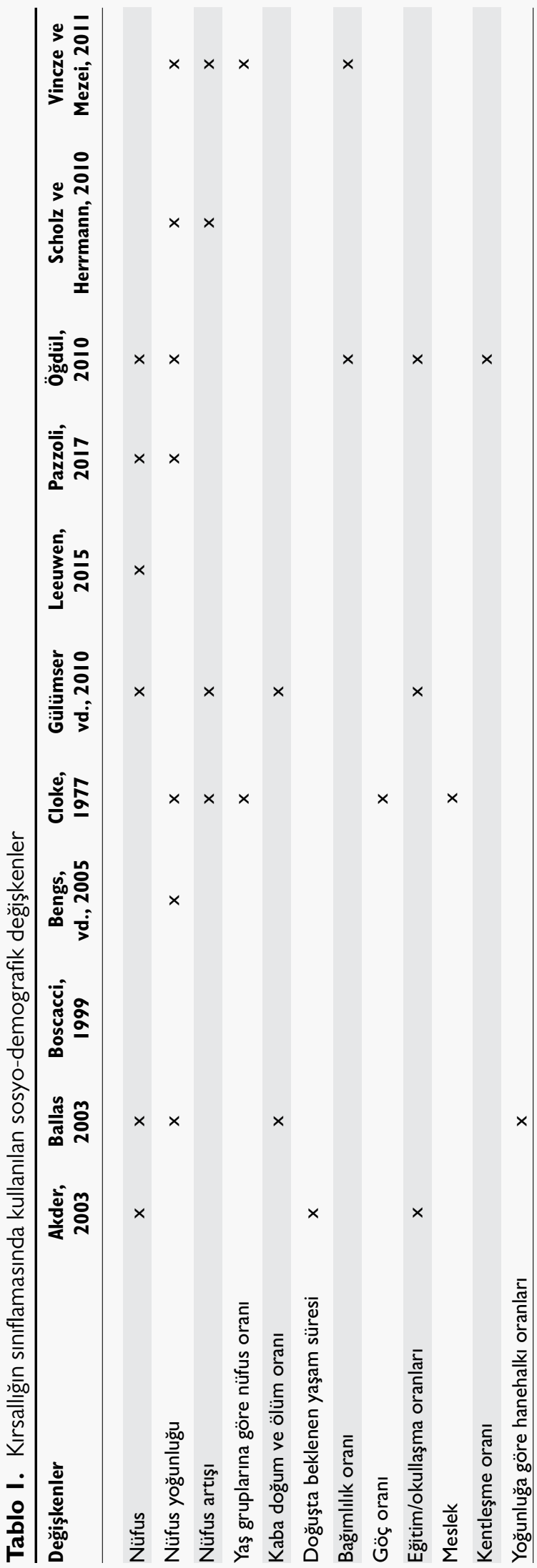

Çalışma, Türkiye illeri kırsallığının sosyo-demografik yapısının zamana bağlı değişimini değerlendirmeyi amaçlamaktadır. Kırsal bağlamların heterojen yapısı ve çalışmanın nüfus ölçütünün yanı sıra sosyo-demografik veriler ile kırsallığın zamana bağlı değişimini ölçme amacı göz önüne alındığında NUTS-3 düzeyinde çok değişkenli bir süreç izlenmiştir. Son yıllarda kırsal alanın tanımlanması ve sınıflaması çalışmalarında artan sayıda çok değişkenli analiz bulunmakta olup; çalışma kümeleme analizi yöntemleri ile gerçekleştirilmiştir. Çalışmanın ilk bölümünde kırsal alan ve kırsallık boyutlarında kuramsal bir çerçeveye; metodoloji kısmında yöntem, değişken seçimi ve değişkenlerin ülkedeki yansımalarına yer verilmiştir. Son bölümde ise; sosyodemografik kırsallık değişkenleri kullanılarak yapılan kümeleme analizleri sonrasında ortaya çıkan kümelerin zamana bağlı değişiminin il, alt bölge ve bölge düzeyinde değerlendirilmesi yapılmıştır. Belirlenen çoklu sınıflama ve çok değişkenli süreç ile sosyo-demografik boyutta hem kırsal alanlar için tanımlayıcı bir değerlendirme yapılması, hem de politika etkilerinin ölçülebileceği bir temelin sağlanması hedeflenmektedir.

\section{Metodolojik Çalışmalar}

Çok değişkenli veya büyük bilimsel verileri analiz etmek ve düzenlemek için kullanılan bir yöntem olan kümeleme analizi birbirine yüksek derecede benzerlik gösterebilecek verilerin aynı grupta olacak şekilde birkaç kümeye bölünmesini amaçlamaktadır (Everitt, 1993; Shih, vd. 2010). Bir kümedeki benzerlik derecesi, her eksenin özelliğini temsil ettiği sistemle arasındaki mesafeyle tanımlanır. Birbirine yakın toplulukların aynı kümede gruplandırılma olasılıkları daha yüksektir (Vıncze ve Mezei, 20I I). Analiz, veri setinin farklı sınıflar veya kümeler içerip içermediğini ve içeriyorsa bu kümelerin tespit edilmesini amaçlar (Hajizadeh, vd., 2010). Kümeleme analizinde geçerli ve anlamlı sonuçlara ulaşabilmek için önemli değişkenlerin seçilmesi ve küme sayısının doğru belirlenmesi gerekir (Punj ve Stevvart, 1983). Küme sayısına karar vermek için geliştirilen en temel ölçütlerden biri $\mathrm{N}$ gözlem sayısını göstermek üzere küme sayısı $k=(\mathrm{N} / 2) \mathrm{l} / 2$ ifadesi ile hesaplanabilir (Tatlıdil, 1992; Çakmak vd, 2005).

Belirli bir ölçü biriminde iki birim birbirlerine en uzak olacak şekilde kümelenirken, ölçü birimleri değiştiğinde birbirlerine daha yakın hale gelerek bireyler arasındaki uzaklıkların sırası değişebilmektedir. Bu nedenle uzaklık hesaplamasından önce değişkenlerin standartlaştırılması yoluna gidilmektedir (Aldenderfer ve Blashfield, 1984; Çakmak, 1999 aktaran Tekin, 2018). NUTS 3 düzeyinde kırsallığın sosyo-demografik yapısının zamana bağlı değişimini karşılaştırmayı amaçlayan çalışmanın ilk aşamasında hiyerarşik kümeleme yöntemlerinden biri olan "Ward Kümeleme Analizi” (kareli Öklid Uzaklığı ile) küme sayısını belirleyebilmek amacıyla yapılmış olup, sonrasında “íki Adımlı Kümeleme Analizi (Two-Step Cluster)" yöntemi kullanılmıştır. 
I) Ward Kümeleme Analizi: Bireysel kümeler olarak başlayan, adım adım en benzer kümelerin bir araya getirildiği sürecin sonunda tüm değişkenlerin tek kümede toplandığı bir dizi adımı içermektedir (Clatworthy vd., 2005). Analiz, verileri bir yakınlık matrisinde düzenlenmek amacıyla tasarlanmış olup, mümkün olan en düşük küme içi varyansı türetmek amacıyla kümeleri birleştirmektedir (Stefurak vd., 2004). Bu yöntemde araştırmacının kümeleri tanımlamak için en uygun küme sayısına karar vermesi gerekmektedir (Clatworthy vd., 2005).

2) İki Adımlı Kümeleme (Two Step Cluster) Yöntemi; hiyerarşik olmayan kümeleme tekniklerinden "K Ortalamalar" ve hiyerarşik tekniklerinden "Ward'ın En Küçük Varyans” tekniklerini birleştirilmesi ile oluşan hibrid kümeleme tekniğidir (Ceylan vd., 2017). Nicel ve nitel değişkenleri aynı anda kullanmaya izin veren, ilk adımda ön kümeleri belirleyen ardından hiyerarşik kümelemeyi gerçekleştiren tek geçişli bir veri yaklaşımıdır (Wu vd., 2016; Michailidou vd., 2009). Yöntemin ön kümeleme aşamasında veriler tek tek taranarak mevcut durumun önceden oluşturulmuş kümelerle birleştirilip birleştirilmeyeceğine, mesafe ölçütüne göre yeni bir küme başlatıp başlatmayacağına karar verilmektedir (Michailidou vd., 2009). Küme adımında ise; ön küme adımından elde edilen alt kümelere göre standart hiyerarşik kümeleme algoritması kullanılarak veriler istenen sayıda kümede gruplandırılmaktadır (Satish ve Bharadhwaj, 2010). Bu algoritmanın en önemli özellikleri; büyük veri setlerinde uygulanabilmesi, kategorik ve sürekli değişkenleri işleyebilmesi, otomatik olarak en uygun küme sayısını belirleyebilmesi ve elde edilen kümelerle uyum sağlamayan gözlemlerin istendiğinde veriden ayıklanabilmesidir (Ceylan vd., 2017).

Çalışmanın takip eden aşamasında yurt içi/yurt dışı yazından elde edilen kırsallığı anlatmada kullanılan sosyo-demografik değişkenler belirlenmiş; değişkenlerin Türkiye illerindeki değerlendirmesi hakkında bilgi verilmiştir. Türkiye NUTS 3 düzeyinde yapılan çalışmada kırsal alanın sosyo-demografik yapısını anlatan değişkenler Türkiye İstatistik Kurumu'nun bölgesel ve il düzeyindeki 2007, 2012 ve 2018 yıllarına ait 9 sosyo-demografik değişkenden oluşmaktadır. Kırsal yazına ek olarak ülkedeki karşılaştırılabilir veri varlığı da değişkenlerin belirlenmesinde etkili olmuştur (Tablo 2).

Toplam nüfus ve köy nüfusu; Türkiye'de Cumhuriyetin ilk yıllarından itibaren kır-kent arasındaki farklılıkların azaltılması yönünde çeşitli çalışmalar yapılmış olmasına rağmen kırsal ve kentsel nüfus arasındaki fark günden güne daha da artmıştır. Bugün 2018 yılı itibari ile yaklaşık 82 milyon olan ülke nüfusunun sadece 6 milyonu kırsal alanlarda yaşamaktadır. Kırsal alanlarda görülen nüfusun azalmasında; göçün yanı sıra 2012 yılı sonrasında yasalar ile değişen köy statüsü etkili olmuştur.
Tablo 2. Seçilmiş sosyo-demografik değişkenler ile veri kaynakları

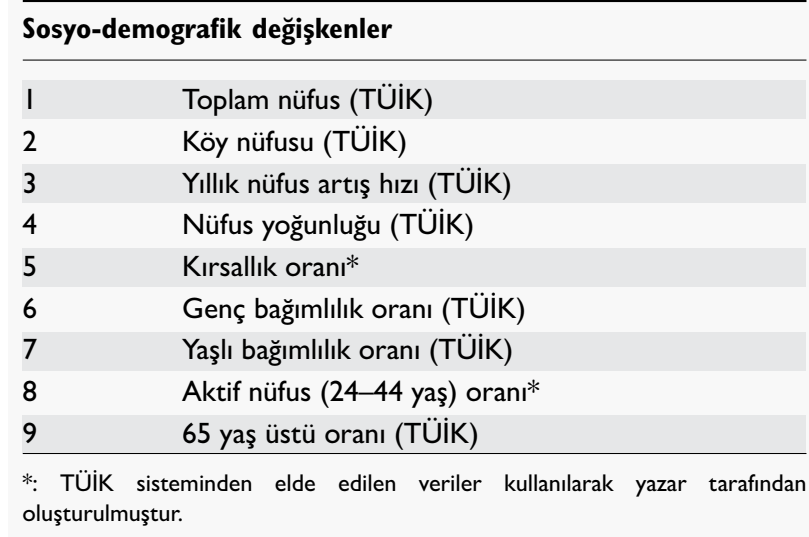

Nüfus Yoğunluğu; kırsallığı tanımlamada kullanılabilecek bir değişken olup ülke ortalama nüfus yoğunluğu her yıl artış göstermektedir. 2018 yılı itibari ile $108 \mathrm{kişi} / \mathrm{km}^{2}$ olan ülke ortalama nüfus yoğunluğunun üstünde 24 il bulunmaktadır.

Toplam Kırsallık Oranı; OECD'nin NUTS 3 düzeyinde yapılan tanımına göre Türkiye illerinin 2018 yılı kırsallık oranları hesaplandığında ülkede 5 adet "Baskın Kırsal Bölge”, 3I adet "Baskın Kentsel Bölge" 45 adet "Önemli Ölçüde Kırsal Bölge" olarak tanımlanabilecek il bulunmaktadır. Ardahan, Bartın, Muş, Kars ve Gümüşhane illerinin Baskın Kırsal ve ülke genelinde var olan 30 adet büyükşehir (R.G. Sayı: 28489) ile Kırıkkale ilinin de Baskın Kentsel Bölge olduğu görülmüştür. Türkiye illerinin büyük bir bölümü ise "Önemli Ölçüde Kırsal” olarak tanımlanabilir (Tablo 3).

Yıllık Nüfus Artış Hızı: 2018 yılı nüfus sayımına göre; ülke ortalama yıllık nüfus artışı 14,7 (binde) olup ortalama üstünde 32 il vardır. Çankırı ilinin 2012 yılı ve sonrası artış hızı ile Gümüşhane ilinin 2018 yılı azalışı dikkat çekicidir. 2018 yılı itibari ile ülkede en fazla nüfus artış hızına Çankırı; en az artış hızına ise Gümüşhane sahiptir.

Bağımlılık Oranları: Cloke (1977) nüfusun yaşlanmasının kırsal bölgelerde daha belirgin olduğunu, yaşı bağımlılık oranlarının da kırsal bölgelerde daha yüksek olduğunu belirtmiştir. Türkiye'de zaman içinde genç bağımlılık oranlarında düşüş yaşanmakla birlikte Şanlıurfa ve Şırnak illeri ülke içinde en yüksek genç bağımlılık oranına, Sinop ve Kastamonu illerinin ise en yüksek yaşlı bağımlılık oranına sahip illerdir.

\section{Kümeleme Analizleri ve Mekânsal Yansımalarının Değerlendirilmesi}

Kırsallığın sosyo-demografik bağlamda kümelenmesi ve zamana bağlı karşılaştırılabilmesi amacıyla hiyerarşik (Ward) ve 
Tablo 3. Türkiye illerinin kırsallık durumu ve baskınlık oranları (2018)

\begin{tabular}{|c|c|}
\hline $\begin{array}{l}\text { 3askın kırsal } \\
\text { ölgeler }\end{array}$ & $\begin{array}{l}\text { rdahan }(60,2) \text {, Bartın }(58,3) \text {, Muş }(55,9) \text {, Kars } \\
53,0) \text {, Gümüşhane }(50,7)\end{array}$ \\
\hline $\begin{array}{l}\text { Önemli ölçüde } \\
\text { kırsal kölgeler }\end{array}$ & 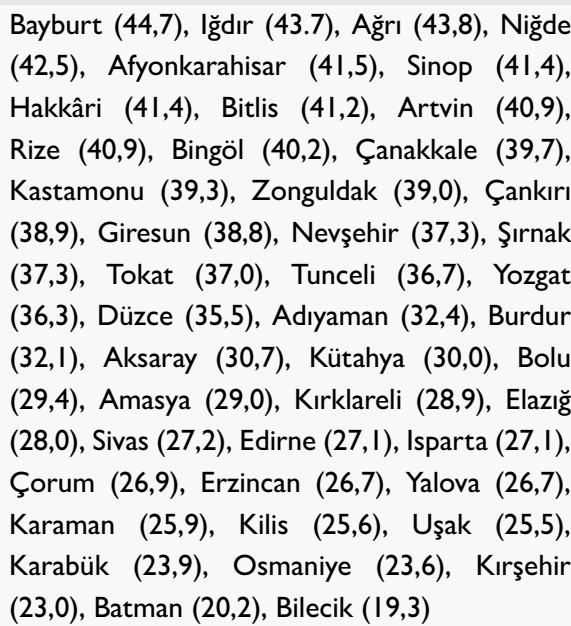 \\
\hline $\begin{array}{l}\text { Baskın kentsel } \\
\text { bölgeler }\end{array}$ & $\begin{array}{l}\text { Kırıkkale (I4.3), Adana (0), Ankara (0), Antalya } \\
(0) \text {, Aydın (0), Balıkesir (0), Bursa(0), Denizli (0), } \\
\text { Diyarbakır (0), Erzurum (0), Eskişehir (0), } \\
\text { Gaziantep (0), Hatay (0), İstanbul (0), İzmir (0), } \\
\text { Kahramanmaraş (0), Kayseri (0), Kocaeli (0), } \\
\text { Konya (0), Malatya (0), Manisa (0), Mardin (0), } \\
\text { Mersin (0), Muğla (0), Ordu (0), Sakarya (0), } \\
\text { Samsun (0), Şanlıurfa (0), Tekirdağ (0), Trabzon } \\
(0) \text {, Van (0) }\end{array}$ \\
\hline
\end{tabular}

hiyerarşik olmayan (K-means) kümeleme tekniklerinin birleştirilmesi ile oluşan "iki Adımlı Kümeleme Analizi" (Two Step Analysis) kullanılmıştır. 2007, 2012 ve 2018 yıllarına ait "sosyo-demografik", değişkenler ile üç aşamalı bir kümeleme süreci gerçekleştirilmiş olup; yapılan kümelemeler sonucunda Türkiye illerinin kırsalık durumları, analiz sonuçları ve mekânsal dağılımları haritalanarak yorumlanmışıı. Çalışmada standartlaştırılmış ve standartlaştııılmamıs veriler ve SPSS 25.0 paket programı yardımıyla kümeleme analizleri yapılmış olup, yorum ve değerlendirme aşamasında standartlaştırılmış veriler kullanılmıştır.

Aşama I. İki Adımlı Kümeleme Analizi: Kırsalıı̆ın sosyo-demografik yapısını tanımlama amacıyla belirlenen 2007 yılına ait standartlaştırılmış 9 sosyo-demografik değişken ile öncelikli olarak İki Adımlı Kümeleme Analizi yapılmıştır. Program tarafından küme sayısının otomatik olarak belirlendiği bu ilk aşamada 3 küme oluşmuş, analiz sonucunda oluşan kümelerin ilkinde 53, ikincisinde 16 , üçüncüsünde ise 12 il yer almıştır. Analiz sonucunda oluşan küme sayısının ülkenin kırsal yapısındaki çeşitliliği yansıtamaması nedeniyle kırsallığın değerlendirilmesinde örnekleme yöntemi ile önerilen
3 küme kullanılmamıştır. Küme sayısının belirlenmesi noktasında Ward yöntemi ile oluşan dendogramlardan yararlanılmıştır.

Aşama 2. Ward Kümeleme Analizi: 2007 yılı standartlaştırılmış sosyo-demografik veriler ile yapılan Ward kümeleme analizi sonucu oluşan dendogramların yatay ekseninde kırsallığın sosyo-demografik değişkenleri ve düşey ekseninde illerin birbirine olan uzaklıkları ve ilişkileri görülmektedir. Analiz sonucunda bir birim uzaklıkta 15 kümenin oluştuğu, en uygun küme sayısının (kümelere düşen il sayısının yakınlığına göre) 2 birim uzaklıkta oluşan 9 küme ve 3 birim uzaklıktaki 6 küme olduğu görülmüştür. Benzer şekilde 2012 yılı için 3 birim uzaklıkta 7 küme, 2018 yılı için 2 birim uzaklıkta 9 ve 3 birim uzaklıkta 6 küme oluşmaktadır (Tablo 4).

Çalışmada farklı yıllara ait değişkenler ile oluşacak kümeler arasında karşılaşıırma yapılabilmesi amacıyla her yıl için ortak bir küme sayısı belirlenmesi hedeflenmiştir. İki Adımlı Kümeleme Analizinde kullanılacak ve 81 ilin çeşitliliğini yansıtabilecek küme sayısının, küme sayısı formülünün ve Ward metodunun sayısal değerlerinin benzer şekilde işaret ettiği "6" olmasına karar verilmiştir.

Adım 3. Belirlenen Küme Sayısına Göre İki Adımlı Kümeleme Analizi: Küme sayısının 6 olarak belirlenmesinin ardından İki Adımlı Kümeleme analizi tekrarlanmıs; 2007 yılı kümelerinin oluşmasında en önemli değişkenin "nüfus yoğunluğu", en az etkili değişkenin ise "kırsal oranı" olduğu görülmüştür (Tablo 5).

2007 yılına ait değişkenler ile yapılan İki Adımlı Kümeleme analizi sonucunda oluşan değişken değerlerinin kümelere göre dağııımları incelenmiş, kümeler arasında tüm değişkenlere ait "Mean" değerleri karşılaştırılarak küme özellikleri belirlenmiştir. 9 değişkenin ve 6 kümenin bütüncül ve karşılaştırmalı değerlendirilmesi sonucunda kümeler barındırdıkları sosyodemografik özelliklere göre adlandırılmışlardır (Tablo 6).

- Kırsallık oranın en yüksek olduğu ve I. kümede yer alan yerleşmeler "kırsal eğilimli yerleşmeler (KEY)",

- Yaşıı bağımlıı̆ı̆ı yüksek, yıllık nüfus artış hızının düşük olduğu 2. küme yerleşmeleri "durağan yerleşmeler (DUY)",

- Yıllık nüfus artış hızının ve aktif nüfus oranının en düşük oluğu ve 3. kümede yer alan yerleşmeler "derin durağan yerleşmeler (DDY)",

- Toplam nüfusun yüksek, kırsallık oranının düşük, yıllık nüfus artı̧̧ hızının ve aktif nüfusun en yüksek olduğu 4. küme yerleşmeleri "dinamik yerleşmeler (DiY)",

Genç bağımlılı̆ıın en yüksek, yıllık nüfus artış hızının yüksek ve aktif nüfus oranının en düşük olduğu ve 5 . kümede yer alan yerleşmeler "genç kırsal yerleşmeler (GKY)", 
Tablo 4. 2007 yılı sosyo-demografik değişkenler ile kırsallığın kümelenmesi (Ward)

\section{2 birim uzaklıktaki 9 küme}

I. küme (I4) Rize, Uşak, Kırklareli, Tunceli, Edirne, Bilecik, Karabük, Isparta, Kırşehir, Kütahya, Amasya, Çorum, Sivas, Tokat

2. küme (II) Denizli, Düzce, Muğla, Ordu, Trabzon, Afyonkarahisar, Manisa, Samsun, Aydın, Balıkesir, Zonguldak

3. küme (9) Kars, Yozgat, Ardahan, Erzincan, Nevşehir, Bayburt, Niğde, Bartın, Gümüşhane

4. küme (8) Kastamonu, Sinop, Bolu, Çanakkale, Çankırı, Giresun, Artvin, Burdur

5. küme (II) Diyarbakır, Van, Şanlıurfa, Siirt, Şırnak, Hakkâri, Batman, Ağrı, Bitlis, Mardin, Muş

6. küme (I5) Aksaray, Bingöl, lğdır, Adıyaman, Erzurum, Kahramanmaraş, Kayseri, Sakarya, Eskişehir, Elazığ, Malatya, Karaman, Kilis, Osmaniye, Kırıkkale

7. küme (4) Antalya, Kocaeli, Tekirdağ, Yalova

8. küme (8) Bursa, İzmir, Ankara, Konya, Mersin, Adana, Hatay, Gaziantep

9. küme (I) İstanbul

\section{3 birim uzaklıktaki 6 küme}

I. küme (34) Rize, Uşak, Kırklareli, Tunceli, Edirne, Bilecik, Karabük, Isparta, Kırşehir, Kütahya, Amasya, Çorum, Sivas, Tokat, Denizli, Düzce, Muğla, Ordu, Trabzon, Afyonkarahisar, Manisa, Samsun, Aydın, Balıkesir, Zonguldak, Kars, Yozgat, Ardahan, Erzincan, Nevşehir, Bayburt, Niğde, Bartın, Gümüşhane

2. küme (8) Kastamonu, Sinop, Bolu, Çanakkale, Çankırı, Giresun, Artvin, Burdur

3. küme (II) Diyarbakır, Van, Şanlıurfa, Siirt, Şırnak, Hakkâri, Batman, Ağrı, Bitlis, Mardin, Muş

4. küme (I5) Aksaray, Bingöl, Iğdır, Adıyaman, Erzurum, Kahramanmaraş, Kayseri, Sakarya, Eskişehir, Elazığ, Malatya, Karaman, Kilis, Osmaniye, Kırıkkale

5. küme(I2) Antalya, Kocaeli, Tekirdağ, Yalova, Bursa, İzmir, Ankara, Konya, Mersin, Adana, Hatay, Gaziantep

6. küme (I) İstanbul

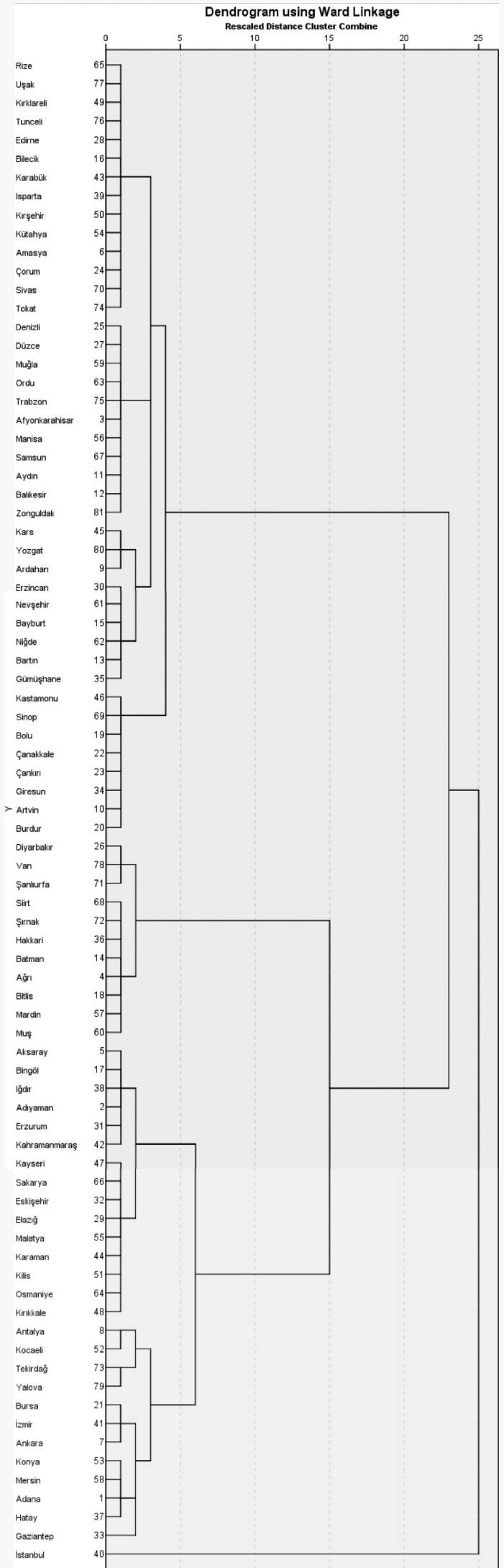




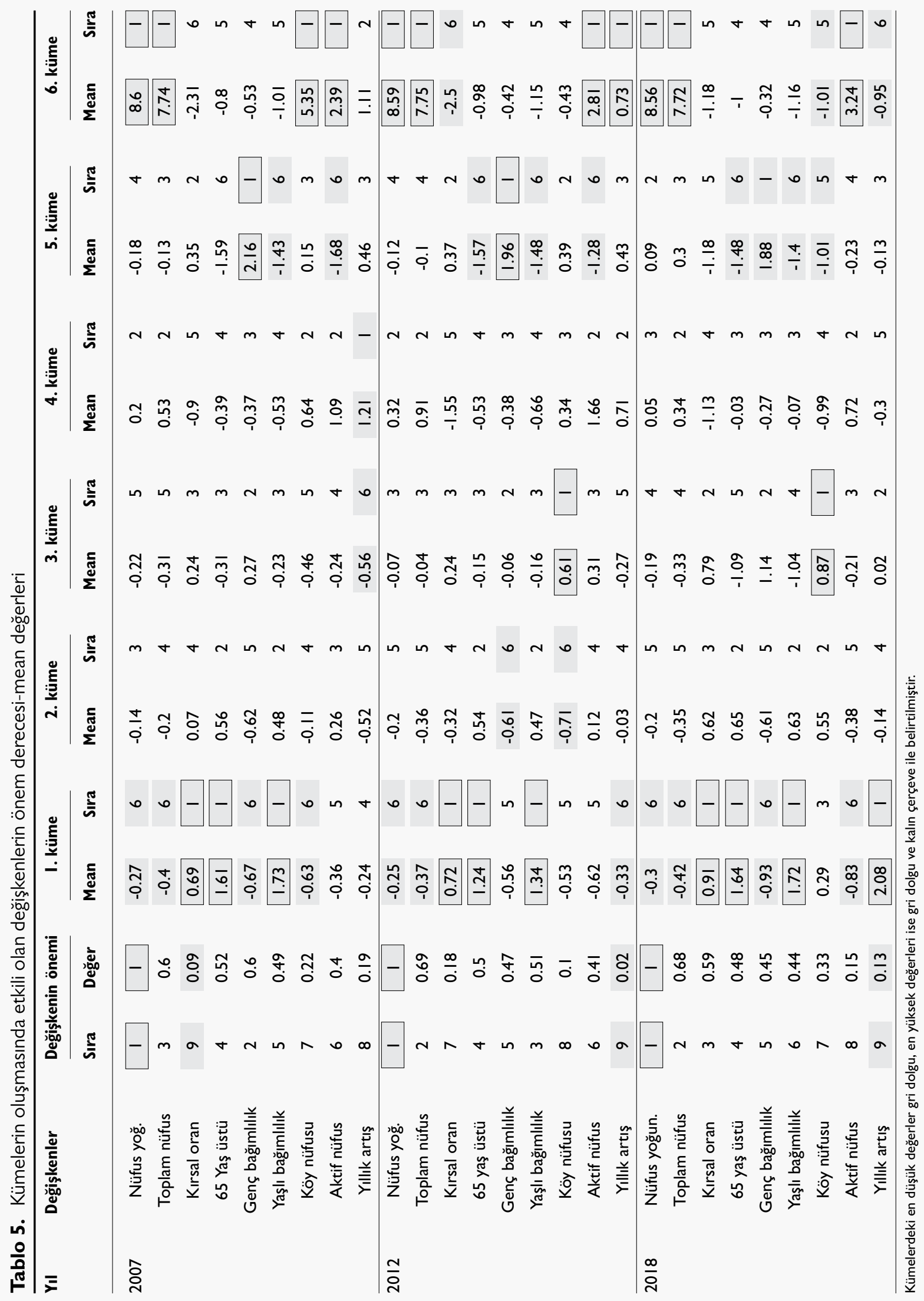


Tablo 6. Türkiye illeri kırsallığının sosyo-demografik açıdan kümelenmesi

\begin{tabular}{|c|c|c|}
\hline Yוl & Küme ve il sayısı & Kümede yer alan iller (iki adımlı kümeleme) \\
\hline \multirow[t]{6}{*}{2007} & $\begin{array}{l}\text { Kırsal eğilimli yerleşmeler (KEY) } \\
(10 \text { il-\%I2,3) }\end{array}$ & Artvin, Bartın, Bolu, Burdur, Çanakkale, Çankırı, Giresun, Gümüşhane, Kastamonu, Sinop \\
\hline & $\begin{array}{l}\text { Durağan yerleşmeler (DUY) } \\
(25 \text { il-\%30,9) }\end{array}$ & $\begin{array}{l}\text { Afyonkarahisar, Amasya, Aydın, Balıkesir, Bilecik, Çorum, Denizli, Düzce, Edirne, Erzincan, } \\
\text { Isparta, Karabük, Kırklareli, Kırşehir, Kütahya, Manisa, Ordu, Rize, Samsun, Sivas, Tokat, } \\
\text { Trabzon, Tunceli, Uşak, Zonguldak }\end{array}$ \\
\hline & $\begin{array}{l}\text { Derin durağan yerleşmeler (DDY) } \\
(18 \text { il-\%22,2) }\end{array}$ & $\begin{array}{l}\text { Adıyaman, Aksaray, Ardahan, Bayburt, Bingöl, Elazı̆̆, Erzurum, Iğdır, Kahramanmaraş, } \\
\text { Karaman, Kars, Kırıkkale, Kilis, Malatya, Nevşehir, Niğde, Osmaniye, Yozgat }\end{array}$ \\
\hline & $\begin{array}{l}\text { Dinamik yerleşmeler (DiY) } \\
(|6 \mathrm{il}-\%| 9,8)\end{array}$ & $\begin{array}{l}\text { Adana, Ankara, Antalya, Bursa, Eskişehir, Gaziantep, Hatay, İzmir, Kayseri, Kocaeli, Konya, } \\
\text { Mersin, Muğla, Sakarya, Tekirdağ, Yalova }\end{array}$ \\
\hline & $\begin{array}{l}\text { Genç kırsal yerleşmeler (GKY) } \\
(\mathrm{II} \text { il-\%।3,6) }\end{array}$ & Ağrı, Batman, Bitlis, Diyarbakır, Hakkâri, Mardin, Muş, Siirt, Şanlıurfa, Şırnak, Van \\
\hline & $\begin{array}{l}\text { Çekici yerleşmeler/Büyüme kutbu } \\
\text { (ÇY/BK) }(I \text { il-\%I,2) }\end{array}$ & İstanbul \\
\hline \multirow[t]{6}{*}{2012} & $\begin{array}{l}\text { Kırsal eğilimli yerleşmeler (KEY) } \\
(\mid 5 \text { il-\%।8,5) }\end{array}$ & $\begin{array}{l}\text { Artvin, Bartın, Burdur, Çanakkale, Çankırı, Giresun, Gümüşhane, Kastamonu, Sinop } \\
\text { Eklenenler: Amasya (DUY), Ardahan (DDY), Bayburt (DDY), Çorum (DUY), Ordu } \\
\text { (DUY), Yozgat (DDY) }\end{array}$ \\
\hline & $\begin{array}{l}\text { Durağan yerleşmeler (DUY) } \\
(20 \text { il-\%24,7) }\end{array}$ & $\begin{array}{l}\text { Bilecik, Edirne, Erzincan, Isparta, Karabük, Kırklareli, Kırşehir, Kütahya, Rize, Sivas, Tokat, } \\
\text { Tunceli, Uşak } \\
\text { Eklenenler: Bolu (KEY), Eskişehir (DiY), Karaman (DDY), Kırıkkale (DDY), Kilis (DDY), } \\
\text { Nevşehir (DDY), Yalova (DiY) }\end{array}$ \\
\hline & $\begin{array}{l}\text { Derin durağan yerleşmeler (DDY) } \\
(24 \text { il-\%29,6) }\end{array}$ & $\begin{array}{l}\text { Adıyaman, Aksaray, Bingöl, Elazı̆̆, Erzurum, Kahramanmaraş, Kars, Malatya, Niğde, } \\
\text { Osmaniye } \\
\text { Eklenenler: Afyonkarahisar(DY), Aydın (DY), Balıkesir (DY), Denizli (DY), Düzce (DY), } \\
\text { Hatay (DiY), Konya (DiY), Manisa (DY), Mersin (DiY), Muğla (DIY), Sakarya (DIY), } \\
\text { Samsun (DY), Trabzon (DY), Zonguldak (DY) }\end{array}$ \\
\hline & $\begin{array}{l}\text { Dinamik yerleşmeler (DiY) } \\
(8 \text { il-\%9,9) }\end{array}$ & $\begin{array}{l}\text { Adana, Ankara, Antalya, Bursa, İzmir, Kayseri, Kocaeli, Tekirdağ } \\
\text { Eklenenler: - }\end{array}$ \\
\hline & $\begin{array}{l}\text { Genç kırsal yerleşmeler (GKY) } \\
(13 \text { il-\%I6) }\end{array}$ & $\begin{array}{l}\text { Ağrı, Batman, Bitlis, Diyarbakır, Hakkâri, Mardin, Muş, Siirt, Şanlıurfa, Şırnak, Van } \\
\text { Eklenenler: Gaziantep (DIY), Iğdır (DDY) }\end{array}$ \\
\hline & $\begin{array}{l}\text { Çekici yerleşmeler/Büyüme kutbu } \\
\text { (ÇY/BK) (I il-\%I,2) }\end{array}$ & İstanbul \\
\hline \multirow[t]{5}{*}{2018} & $\begin{array}{l}\text { Kırsal eğilimli yerleşmeler (KEY) } \\
(6 \text { il-\%7,4) }\end{array}$ & $\begin{array}{l}\text { Artvin, Çankırı, Giresun, Kastamonu, Sinop } \\
\text { Eklenenler: Tunceli (DY) }\end{array}$ \\
\hline & $\begin{array}{l}\text { Durağan yerleşmeler (DUY) } \\
(28 \text { il-\%34,6) }\end{array}$ & $\begin{array}{l}\text { Afyonkarahisar, Amasya, Çorum, Düzce, Edirne, Erzincan, Isparta, Karabük, Kırklareli, } \\
\text { Kırşehir, Kütahya, Rize, Sivas, Tokat, Uşak, Zonguldak } \\
\text { Eklenenler: Ardahan (DDY), Bartın(KEY), Bayburt (DDY), Bolu, Burdur (KEY), } \\
\text { Çanakkale (KEY), Gümüşhane (KEY), Karaman (DDY), Kırıkkale (DDY), Nevşehir } \\
\text { (DDY), Yalova (DIY), Yozgat (DDY) }\end{array}$ \\
\hline & $\begin{array}{l}\text { Derin durağan yerleşmeler (DDY) } \\
(16 \text { il-\%19,8) }\end{array}$ & $\begin{array}{l}\text { Adıyaman, Aksaray, Bingöl, Elazığ, Iğdır, Kars, Kilis, Niğde, Osmaniye } \\
\text { Eklenenler: Ağrı (GKY), Batman (GKY), Bitlis (GKY), Hakkâri (GKY), Muş (GKY), Siirt } \\
(G K Y) \text {, Şırnak (GKY) }\end{array}$ \\
\hline & $\begin{array}{l}\text { Dinamik yerleşmeler (DiY) } \\
(24 \text { il-\%29,6) }\end{array}$ & $\begin{array}{l}\text { Ankara, Antalya, Bursa, Eskişehir, İzmir, Kayseri, Kocaeli, Konya, Mersin, Muğla, Sakarya, } \\
\text { Tekirdağ } \\
\text { Eklenenler: Aydın (DUY), Balıkesir (DUY), Bilecik (DUY), Denizli (DUY), Erzurum } \\
\text { (DDY), Kahramanmaraş (DDY), Malatya (DDY), Manisa (DUY), Ordu (DUY), Samsun } \\
\text { (DUY), Trabzon (DUY) }\end{array}$ \\
\hline & $\begin{array}{l}\text { Genç kırsal yerleşmeler (GKY) } \\
(6 \text { il-\%7,4) }\end{array}$ & $\begin{array}{l}\text { Diyarbakır, Mardin, Şanlıurfa, Van } \\
\text { Eklenenler: Gaziantep (DiY), Hatay (DiY) }\end{array}$ \\
\hline
\end{tabular}

Çekici yerleşmeler/Büyüme kutbu (ÇY/BK) (I il-\%I,2) 


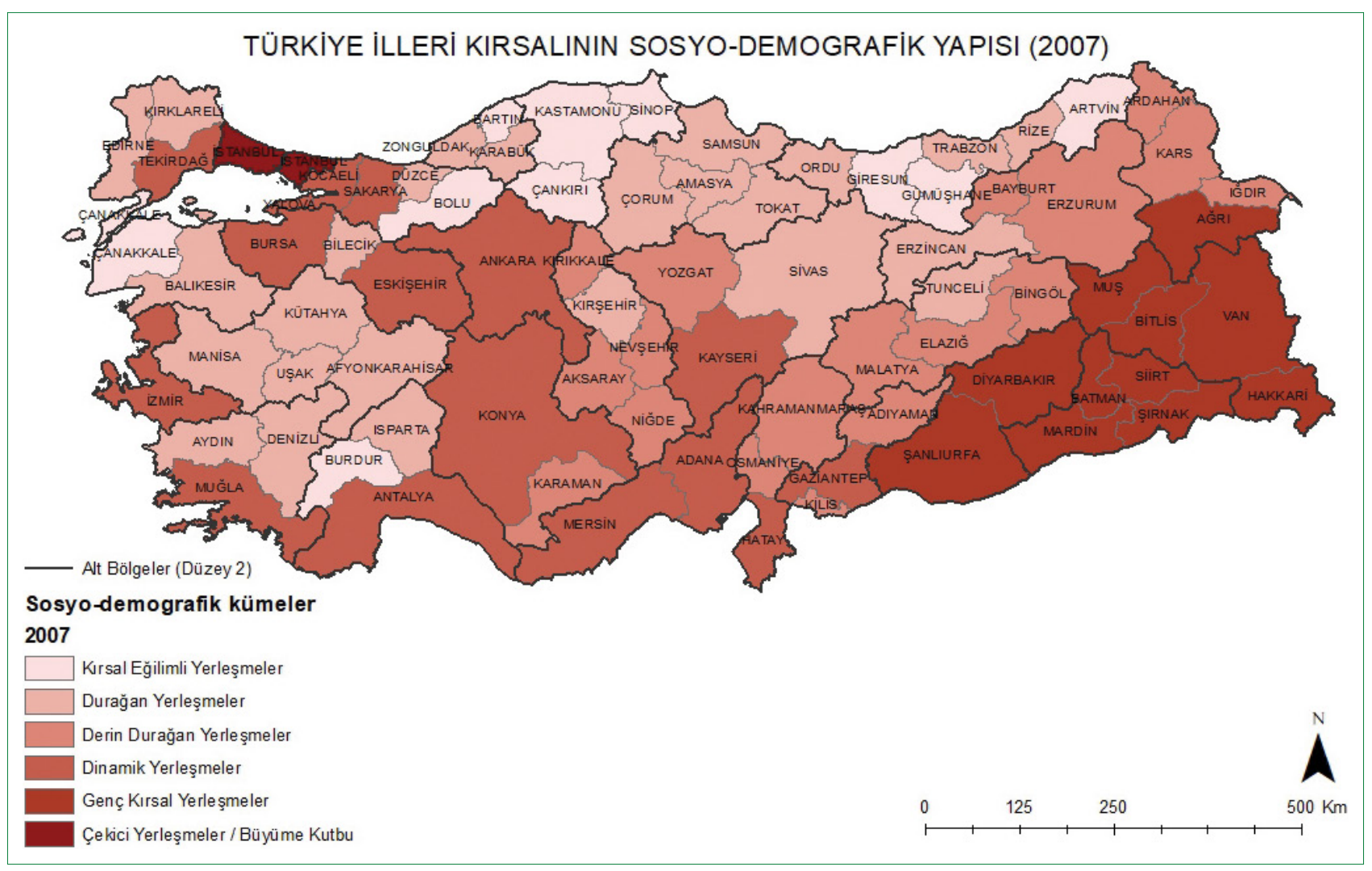

Şekil I. Sosyo-demografik kümelerin mekânsal dağılımı (2007).

- Nüfus yoğunluğu, toplam nüfus ve aktif nüfusun çok yüksek, bağımlıık oranlarının düşük olduğu 6. Küme yerleşmeleri "çekici yerleşmeler/büyüme kutupları (ÇY/BK)" olarak tanımlanmıştır.

2007 yılına ait İki Adımlı Kümeleme analizi sonucunda ülke genelinde en fazla $(\% 30,9)$ "durağan" özellik gösteren il bulunmaktadır. 2012 yılında ülkenin \%29,6'lık kısmını "derin durağan yerleşmeler" kümesinde yer alan iller; 2018 yılında ise ülkenin \%34,6'ık kısmını "durağan yerleşmeler" kümesinde yer alan iller oluşturmakta idi. Çalışmanın bundan sonraki bölümünde 2007 yılına ait değişkenler ile yapılan İki AdımIı Kümeleme Analizi ile tanımlanan (Tablo 6) kümeler esas alınarak geçen iki dönemde il, alt bölge ve bölgelerin sosyodemografik açıdan değerlendirmesi ve kırsalık durumlarının değişimleri tartışıımıştır.

2007 yılı sosyo-demografik değişkenler kullanılarak yapılan kümeleme analizine göre kümelerin oluşmasında en etkili değişkenler "nüfus yoğunluğu" ve "genç bağımlılık oranı", en az etkili değişken ise "kırsalık oranı" olmuştur (Tablo 5). Genel olarak illerin mekânsal yakınlığa sahip illerle beraber homojen bir yapı oluşturduğu ülke genelinde alt bölgelerin birçoğunun kırsal yapıları bakımından çeşitlilik barındırdığı, ülkenin güneydoğu bölümünün ise homojen yapısı dikkat çekmektedir. İstanbul'un (TRIO) beklendiği üzere diğer tüm illerden farklı bir sosyo-demografik yapıya sahip olduğu ve ülke içinde tek başına "çekici yerleşmeler ve büyüme kutbu" kümesinde yer aldığı görülmüştür. Mekânsal yakınlığa sahip Şanlıurfa (TRC2), Mardin (TRC3) ile Van (TRB2) alt bölgesi "genç kırsal yerleşmeler" kümesinde; Samsun (TR 83), Manisa (TR 33) alt bölgesinde bulunan illerinin tümü yaşlı bağımlılı̆ın hızının yüksek - yıllık artış hızının düşük olduğu "durağan yerleşmeler" kümesinde yer almaktadır (Şekil I).

Ayrıca; İzmir (TR 3I), Ankara (TR 5I) ve Adana (TR 62) alt bölgeleri yüksek oranda aktif nüfus barındırmakta olup "dinamik yerleşmeler" özelliği; Kastamonu (TR 82) alt bölgesinin tamamı ise "kırsal eğilimli yerleşme" özelliği göstermektedir. Kocaeli (TR 42), Antalya (TR 6I) ve Kayseri (TR 72) alt bölgeleri ise birden fazla kümeyi barındırmakta olup sosyo-demografik açıdan heterojen bir yapı göstermektedir (Şekil I).

2012 yılına ait sosyo-demografik kümelerin oluşmasında en etkili değişkenler "nüfus yoğunluğu" ve "toplam nüfus" olurken en az etkili değişken "yıllık nüfus artışı"dır (Tablo 5). 2012 yılında kırsal eğilimli, derin durağan ve genç kırsal özellik gösteren yerleşmelerin bir önceki döneme göre sayıları artarken, durağan ve dinamik kümelerde yer alan yerleşme sayıları azalmıştır. Bu dönemde; İstanbul (TRIO) "çekici yerleşmeler ve büyüme kutbu", İzmir (TR 3I) ve Ankara (TR 5I) alt bölgesi “dinamik yerleşmeler”, Kastamonu 


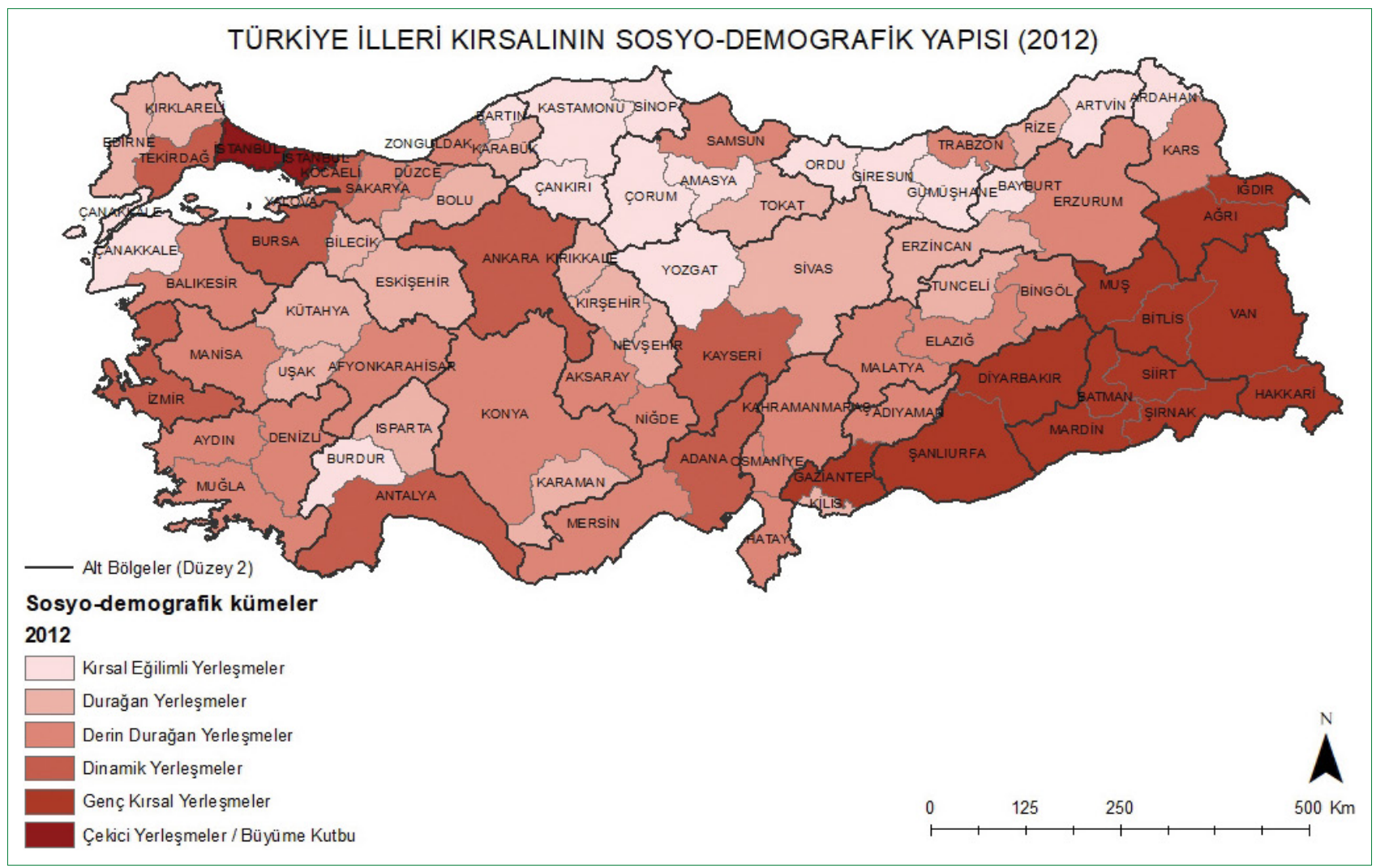

Şekil 2. Sosyo-demografik kümelerin mekânsal dağılımı (20।2).

(TR 82) alt bölgesinin tamamı "kırsal eğilimli yerleşmeler", Şanlıurfa (TRC2), Mardin (TRC3) ve Van (TRB2) alt bölgesi ise "genç kırsal yerleşmeler" kümesinde yer almaya devam etmiştir (Şekil 2).

Aydın (TR 32) ve Hatay (TR 63) alt bölgesi bir önceki dönemden farklı olarak tek bir kümede yer almakta olup; “derin durağan yerleşme” özelliği göstermektedir. Kırıkkale (TR 7I) ve Malatya (TRBI) alt bölgeleri sosyo-demografik açıdan heterojen bir yapıya sahip olup "durağan" ve "derin durağan yerleşmeler” kümesinde; Tekirdağ (TR 2I) ve Bursa (TR4I) alt bölgeleri ise "durağan" ve "dinamik" yerleşmeleri birlikte barındırmaya devam etmektedir. Bu dönemde Adana (TR 62) ve Manisa (TR 33) alt bölgeleri de kendi içlerinde iki farklı kümeye ayrılmaktadır. Ayrıca; diğer tüm alt bölgelerin de bir önceki döneme göre sosyo-demografik yapılarının çeşitlendiği görülmektedir (Şekil 2, Tablo 6).

2018 yılı kümeleme analizi sonucunda sosyo-demografik kümelerin oluşmasında en etkili değişkenler nüfus yoğunluğu" ve "toplam nüfus" ile en az etkili değişken "yıllık nüfus artışı” olmuştur. “Kırsal yerleşmeler”, "genç kırsal yerleşmeler” ve "derin durağan yerleşmeler" kümelerinde yer alan il oran ve sayısının azalırken; "durağan yerleşmeler" ve "dinamik yerleşmeler” kümelerindeki oran ve sayının arttı̆̆ı görülmüştür (Tablo 6).
Diğer iki yılda olduğu gibi İstanbul (TRI0) tek başına "çekici yerleşmeler ve büyüme kutbu”, İzmir (TR 3I) ve Ankara (TR 5I) alt bölgeleri “dinamik yerleşmeler”, Kastamonu (TR 82) alt bölgesinin tamamı "kırsal eğilimli yerleşmeler” kümelerinde yer almaktadır. Şanlıurfa (TRC2) alt bölgesi "genç kırsal yerleşmeler”, Tekirdağ (TR 2I) alt bölgesi “durağan ve dinamik" ve Kırıkkale (TR 7I) alt bölgesi “durağan ve derin durağan yerleşmeler" küme yapılarını devam ettirmiştir. 2006 ve 2012 yıllarında iki veya daha fazla küme barındıran Bursa (TR 4I) alt bölgesinin 20l8'de tek bir homojen küme oluşturduğu ve "dinamik yerleşmeler" kümesinde; Zonguldak (TR 8I) alt bölgesinin ise "durağan yerleşmeler" kümesinde yer aldığı görülmektedir. Adana (TR 62) alt bölgesi sosyo-demografik açıdan homojen bir yapıya sahip olup 2006 yılına benzer şekilde sadece "dinamik yerleşmeler" özelliği göstermektedir. Van (TRB2) ve Mardin (TRC3) alt bölgelerinin sosyo-demografik açıdan genç kırsal yerleşme yapısı 2018 yılı itibari ile çeşitlenmiş olup bölgedeki iller "derin durağan" ve "genç kırsal yerleşmeler" olmak üzere iki ayrı kümeye ayrılmıştır. 2018 yılı itibari ile Aydın (TR32) alt bölgesi tek bir kümede yer almakta olup “dinamik yerleşmeler” özelliği göstermektedir. Ülkenin büyük bir kısmı - Manisa (TR 33), Kocaeli (TR 42), Konya (TR 52), Antalya (TR 6I), Kayseri (TR 72), Samsun (TR 83), Erzurum (TRAI) alt bölgeleri “durağan” ve "dinamik” yerleşmeler olmak üzere iki ayrı kümede yer almaktadır (Şekil 3). 


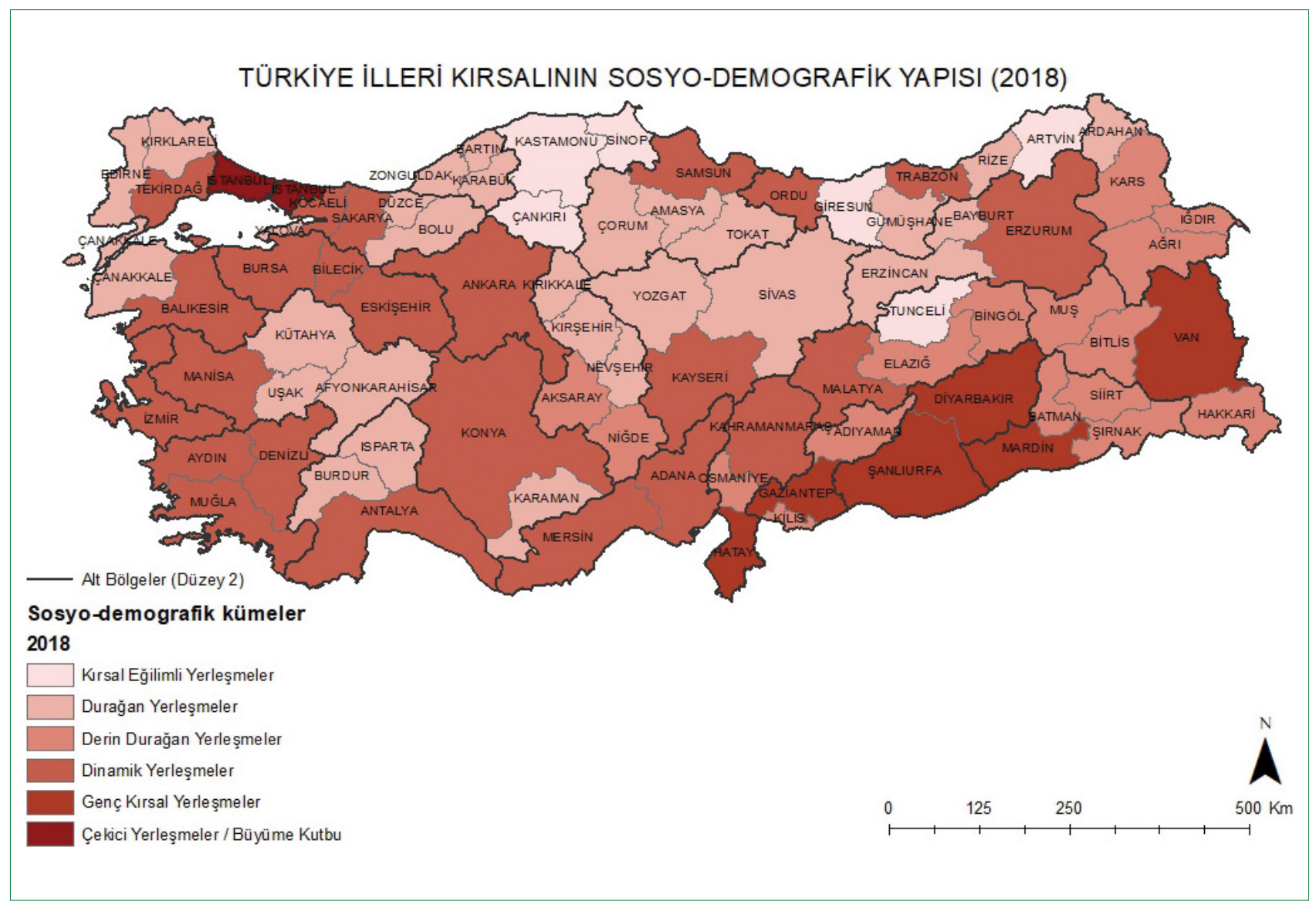

Şekil 3. Sosyo-demografik kümelerin mekânsal dağıımı (20।8).

İki Adımlı Kümeleme analizine göre 2007'den bugüne İstanbul, İzmir, Ankara, Kastamonu ve Şanlıurfa alt bölgeleri sosyo-demografik açıdan sürekli olarak tek bir küme özelliği göstermekte olup homojen bir yapıya sahiptir. Tekirdağ, Balıkesir, Konya, Kırıkkale ve Malatya alt bölgeleri ise en az iki farklı küme özelliğini her üç dönemde de benzer sosyo-demografik yapı özellikleri göstermekte olup "sürekli-heterojen" bir yapıdadır. Aydın, Bursa, Kocaeli ve Antalya alt bölgelerinin homojenliği zaman içinde artarken; Manisa, Samsun, Trabzon ve Mardin alt bölgelerinin homojenliği ise azalmaktadır (Şekil 4).

Kırsallı̆ıın sosyo-demografik küme yapısı il düzeyinde zamana bağlı olarak değerlendirildiğinde ise; geçen 15 yılda TR 90 alt bölgesinde yer alan Artvin ve Giresun illeri ile TR 82 alt bölgesinde bulunan Kastamonu, Sinop ve Çankırı "kırsal eğilimli yerleşmeler" kümesinde yer almış ve sosyo-demografik kümelerinde herhangi bir değişiklik olmamıştır. TR 21 alt bölgesinde yer alan Kırklareli ve Edirne, TR33 alt bölgesinde yer alan Kütahya ve Uşak, Isparta (TR6I), Kırşehir (TR7I), Sivas (TR72), Karabük (TR8I), Tokat (TR83), Rize (TR90), Erzincan (TRAI) illerinin 2007-2012-2018 yillarında "durağan yerleşmeler" özelliği gösterdiği görülmektedir. Benzer şekilde TR7 alt bölgesinde ki Aksaray ve Niğde, TRBI alt böl- gesindeki Elazı̆̆ ve Bingöl illeri, Kars (TRA2), Osmaniye (TR 63), Adıyaman (TRCI) illeri ise her üç dönemde de "derin durağan yerleşmeler" kümesinin özelliğini göstermektedir. Sosyo-demografik açıdan Tekirdağ (TR2I), İzmir (TR3I), Bursa (TR4I), Antalya (TR6I), Ankara (TR5I), Adana (TR62), Kayseri (TR72) illeri “dinamik yerleşmeler"; Van (TRB2), Mardin (TRC3), Şanlıurfa ve Diyarbakır (TRC2) illeri "genç kırsal yerleşmeler" ve İstanbul (TRI0) "çekici yerleşmeler" yapısını zaman içinde korumuştur (Şekil 4, Tablo 7).

Bunların yanı sıra; 2007 yııında "kırsal eğilimli yerleşmeler" kümesinde yer alan Bolu (TR42); "durağan yerleşmeler" kümesinde yer alan Balıkesir (TR22), Manisa (TR33), Aydın (TR32), Samsun (TR83), Ordu ve Trabzon (TR90) ise küme yapıları bakımından her üç dönemde de farklı sosyo-demografik özellikler göstermişlerdir. "Derin durağan yerleşmeler" kümesinde yer alan Karaman (TR52), Kırıkkale, Nevşehir (TR7I), Yozgat (TR72), Ardahan (TRA2) ve Bayburt (TRAI); "dinamik yerleşmeler" kümesinde yer alan Hatay (TR63) ve Gaziantep (TRCI) illeri de benzer şekilde 2007'den bugüne farklı kümelerde yer almıştır (Şekil 4, Tablo 7). Alt bölgelerin sosyo-demografik değişkenler kullanılarak oluşan kümeleri ve zamana bağlı homojenliğin değişimi Tablo 7'de verilmiştir. 


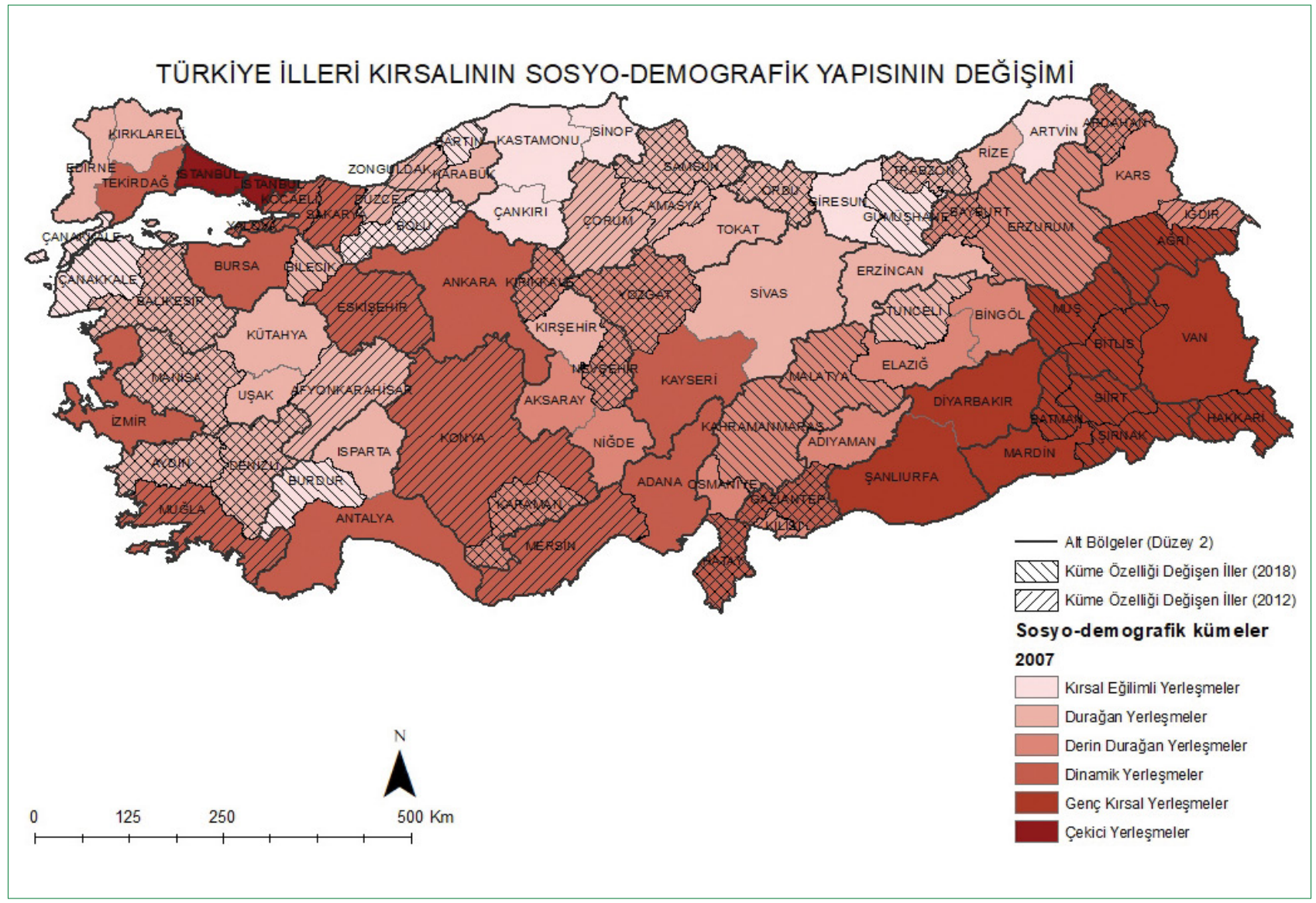

Şekil 4. Sosyo-demografik kümelerin mekânsal dağılımı (20।8).

\section{Sonuç}

Kırsal alanlar; kentsel alanlardan sadece barındırdıkları nüfus bakımından değil, aynı zamanda ekonomi, istihdam, eğitim düzeyi, bilgiye erişim ve göç gibi sosyal, ekonomik, fiziksel, sağlık, kültürel vb. koşullarla da ayrılırlar. Kırsal alanın tanımı ve kırsallık göstergeleri ülkeden ülkeye, ülke içinde ise kurumdan kuruma farklılaşmakta olup alanın bağlamına ve veri varlığına bağlı olarak değişmektedir. Kırsal ve kentsel bileşenlere sıklıkla birbirinden bağımsız yaklaşılsa da aralarında kesin bir sınır bulunmamaktadır. Bugünün mekânsal gelişim politikaları da kentsel ve kırsal alanların işlevsel ilişkilerinin ve politikalarının bütüncül bir şekilde ele alınması gerektiğini vurgulamaktadır. Dünya'da olduğu gibi Türkiye'de de kırsallığın belirsizliği ve kırsal alanların çeşitliliğinin tanınması, kırsal kalkınma politikalarının unsurlarından biri olup kırsallığın farklı ölçeklerde ve içeriklerde ele alınması önemlidir.

NUTS-3 düzeyinde yapılan bu çalışma; illerin kırsallığının sosyo-demografik değişkenler yardımıyla tanımlanmasını ve zamana bağlı değişen yapısını ortaya koymayı amaçlamaktadır. Kırsal alan tipoloji ve sınıflama çalışmaları sosyo-demografik, ekonomik, çevresel vb. tüm dinamikleri birlikte ele almayı gerektirmekte olup bu çalışma ülkedeki kırsallık durumunun yaklaşık I 5 yıllık dönemdeki sosyo-demografik durumunu aktarma hedefine karşın bütüncül ve çok boyutlu bir kırsal tipoloji çalışması özelliği taşımamaktadır. Sosyo-demografik yapının bu süreçte detaylı ele alınışı, kanıta dayalı bu izlenimi ile planlama yoluyla etkili ve verimli kararlar ve/veya önlemler geliştirmeye yardımcı olmak hedeflenmiştir.

Kırsallığın sosyo-demografik göstergeleri ile tanımlanarak il düzeyinde yapılan kümelemeler ve zamana bağlı karşılaştırmalı mekânsal değerlendirmeler sonucunda doğu-batı arasındaki keskinliğin değişim gösterdiği görülmektedir. Ülkenin genç kırsal yerleşme özelliği gösteren güneydoğu bölümü ve paralelinde gelişen derin durağan yerleşme özelliği gösteren iller ile özellikle büyükşehir illerini kapsayan ve dinamik yerleşme özelliği gösteren güney/güney iç kısmı illerinin mekânsal olarak homojen ve sürekli bir yapı gösterdiği görülmüştür. 2012 yılına gelindiğinde güneydoğu üçgeni ile paralelindeki derin durağan illerin dışında mekânsal süreklilik kırılmaktadır. 2018 yılında ise bu kez ülkenin güney ve batı illeri sosyo-demografik açıdan önemli bir mekânsal süreklilik göstermektedir. Dinamik yerleşmelerin bu dağılımında 


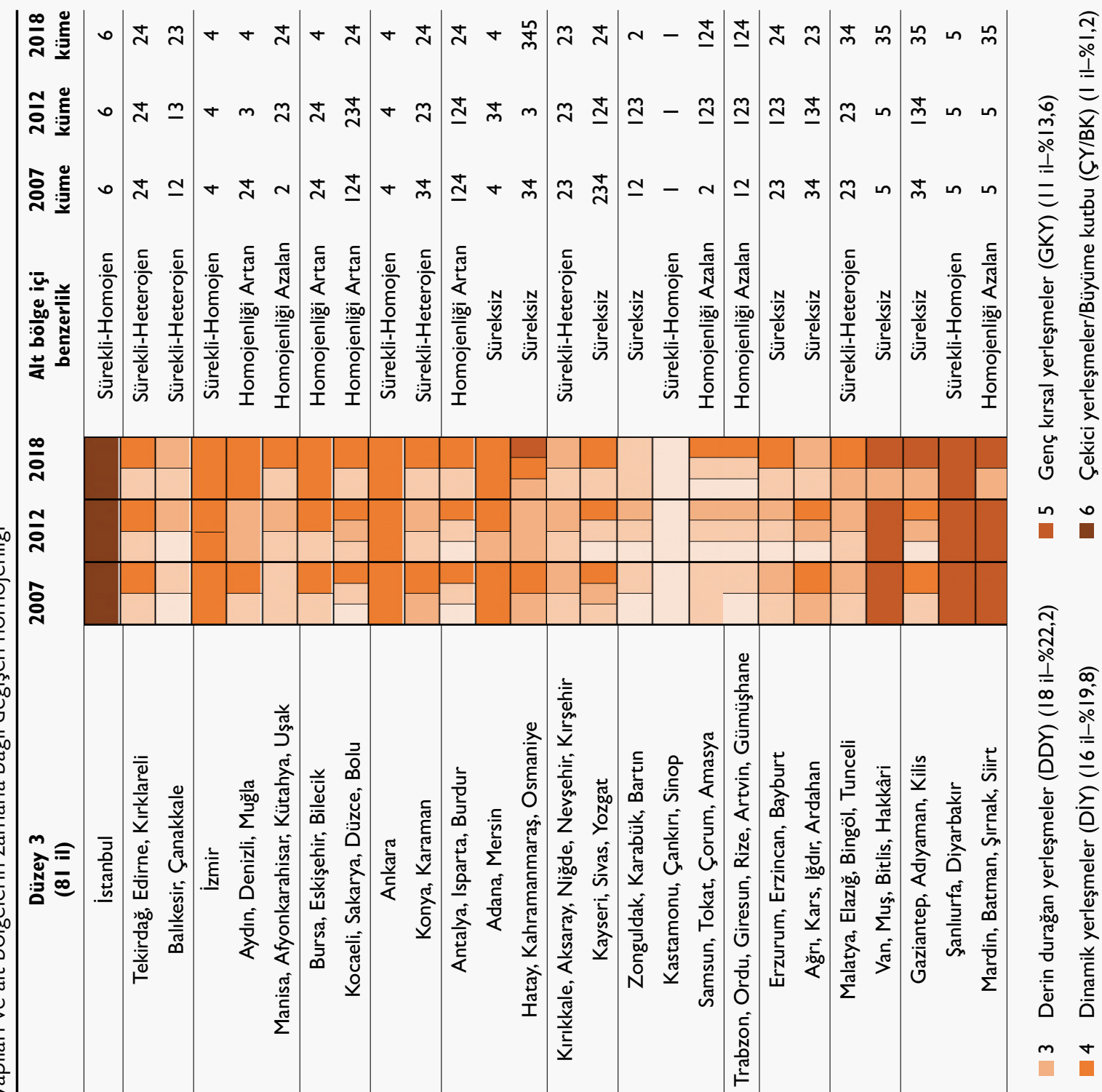

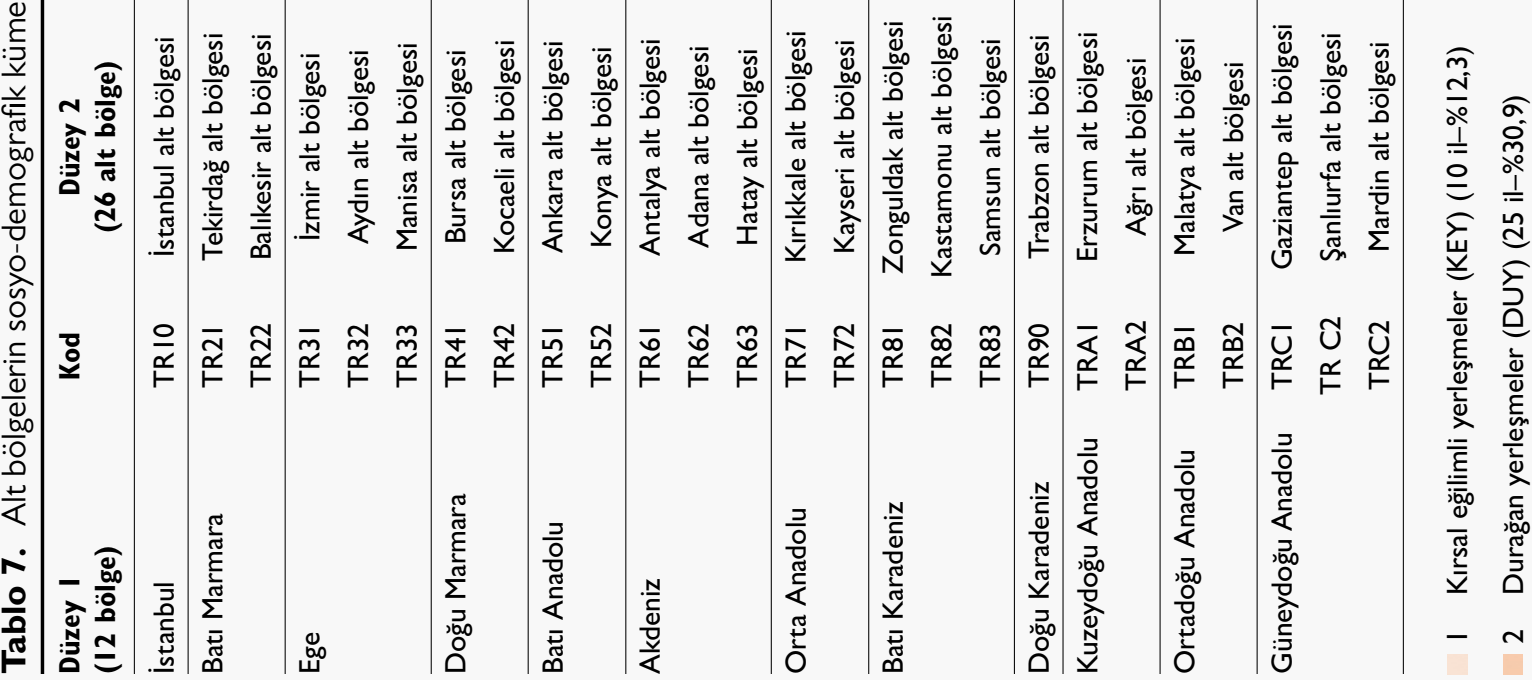


büyükşehir yasası ile şekillenen kırsallık oranları önemli bir etken olduğu söylenebilir. Ayrıca; kırsal kalkınma ve kırsal politika müdahalelerinin sonucunu belirleme noktasında kırsal heterojenliğin önemli bir rolü bulunmakta olup ülke içindeki alt bölgeler önemli ölçüde heterojen yapı özelliği göstermektedir.

Kırsalın sosyo-demografik yapısının çok yönlü ve çok değişkenli süreçler ile ele alınması, güçlü/zayıf yönlerinin ortaya konulması, kentsel ve kırsal karakterli alanların etkileşimini ve bağımlılıklarını dikkate alan sistemlerin önerilmesi ve bunları birleştiren stratejilerin geliştirilmesi bölgelerin bütünleşik olarak yeniden değerlendirilmesini öngören bugünün mekânsal gelişim politikaları açısından gereklidir. Çalışma sonucunda elde edilen kırsallı̆̆ın ülke ve bölge içindeki çeşitliliği karakteristik durumlar yaratmakta olup; kırsal ve kentsel nüfus ihtiyaçlarının çeşitli perspektiflerden ele alınması, ihtiyaçlarının daha iyi anlaşılması, her bir yerin farklı yerel potansiyellerinin tespit edilmesi, aralarındaki etkileşimlerin büyüklüğü ve hassas kümelerin belirlenmesi gelecek açısından önemli ve yol gösterici olacaktır. Son olarak; il ve bölge düzeyinde zamana bağlı yapılan çalışmanın sosyo-demografik karşılaştırmaların yanı sıra ülkenin heterojen yapısını yansıtacak bölgeye özgü sosyal ve demografik politikalar ile planlama kararları üretme noktasında yararlı olacağı düşünülmektedir.

\section{KAYNAKLAR}

Akder, H. (2003). Linking Agricultural Statistics to Other Data Sources for Analysing Rural Indicators of Social Well-Being and Equity, Bildiri, $8^{\text {th }}$ IWG. AGRI Seminar, OECD, Paris.

Aldenderfer, M. S. ve Blashfield, R. K. (1984). Quantitative Applications in the Social Sciences: Cluster analysis Thousand Oaks, CA: SAGE.

Avrupa Komisyonu, (1999). ESDP-European Spatial Development Perspective: Towards Balanced and Sustainable Development of the Territory of the European Union, Report, European Commission, Brussels.

Balestrieri, M. (2014). Rurality and competitiveness. Some observations on the local area: The case of the Sardinian Region. International Journal of Rural Management, 10(2), 173-197.

Ballas, D., Kalogeresis, T., ve Labrianidis, L. (2003). A Comparative Study of Typologies for Rural Areas in Europe, Bildiri, $43^{\text {rd }}$ ERSA Congress. Finlandiya

Baum, S., Trapp, C., \& Weingarten, P. (2004). Typology of rural areas in the CEE new Member States. Assessing rural development of the CAP.

Bengs, C., ve Schmidt-Thomé, K. (2005). ESPON 1.1. 2. Urban Rural Relations in Europe.

Blunden, J. R., Pryce, W. T. R., \& Dreyer, P. (1998). The classification of rural areas in the European context: An exploration of a typology using neural network applications. Regional Studies, 32(2), 149-160.

Bogdanov, N., Meredith, D., \& Efstratoglou, S. (2008). A typology of rural areas in Serbia. Economic annals, 53(177), 7-29.

Boscacci, F., Arcaini, E., Boscacci, F., Camagni, R., Capello, R., \& Porro, G. (1999). A Typology of Rural Areas in Europe. Study Programme on European Spatial Planning Of The European Commission", Milan: Milan Polytechnic.

Bryden, J. (2002, November). Rural development indicators and diversity in the European Union. In conference on "Measuring rural diversity". Washington, DC. Available from http://citeseerx. ist. psu. edu/viewdoc/ download.

Ceylan, Z., Gürsev, S. ve Bulkan, S. (2017). İki Aşamalı Kümeleme Analizi ile Bireysel Emeklilik Sektöründe Müşteri Profilinin Değerlendirilmesi. Bilişim Teknolojileri Dergisi, 10(4), 475-485

Clatworthy, J., Buick, D., Hankins, M., Weinman, J., \& Horne, R. (2005). The use and reporting of cluster analysis in health psychology: A review. British journal of health psychology, 10(3), 329-358.

Cloke, P. J. (1977). An index of rurality for England and Wales. Regional Studies, 11(1), 31-46.

Cloke, P., ve Edwards, G. (1986). Rurality in England and Wales 1981: A Replication of the 1971 index. Regional Studies, 20(4), 289-306.

Coombes, M., \& Raybould, S. (2004). Finding Work in 2001: Urban-Rural Contrasts Across England in Employment Rates and Local Job Availability. Area, 36(2), 202-222

Cromartie, J. B., and L. L. Swanson (1996). Census Tracts More Precisely Define Rural Populations and Areas. Rural Development Perspectives 11 (3): 31-39.

Çakmak, Z. (1999). Kümeleme Analizinde Geçerlilik Problemi Ve Kümeleme Sonuçlarının Değerlendirmesi. Dumlupınar Üniversitesi Sosyal Bilimler Dergisi, 3(3), 187-205.

Çakmak, Z., Uzgören, N., ve Keçek, G. (2005). Kümeleme Analizi Teknikleri ile İllerin Kültürel Yapılarına Göre Sınıflandırılması ve Değişimlerinin İncelenmesi. Dumlupınar Üniversitesi Sosyal Bilimler Dergisi, (12).

Davoudi, S., ve Stead, D. (2002). Urban-Rural Relationships: An İntroduction and Brief History. Built Environment, 28(4), 269-277.

Devlet Planlama Teşkilatı (DPT), 2004. İlçelerin Sosyo-Ekonomik Gelişmişlik Sıralaması Araştırması, Bölgesel Gelişme ve Yapısal Uyum Genel Müdürlüğ̈̈, Ankara.

ESPON (2004) Potentials for Polycentric Development in Europe: ESPON Project 1.1.1. Final Report. 
EUROSTAT, (2005). Nomenclature of Territorial Units for Statistics NUTS (Luxemburg: Statistical Regions of Europe).

EUROSTAT, (2010). A Revised Urban-Rural Typology, Eurostat Regional Yearbook 2010, 239-253

Everitt, B. (1993) Cluster Analysis for Applications Academic Press, New York

Gülümser, A. A., Levent, T. B. ve Nijkamp J. (2010). Türkiyénin Kırsal Yapısı: AB Düzeyinde Bir Karşlaşısırma.

Hajizadeh, E., Ardakani, H. D., \& Shahrabi, J. (2010). Application of Data Mining Techniques in Stock Markets: A Survey. Journal of Economics and International Finance, 2(7), 109-118.

Harrington, V., \& O'Donoghue, D. (1998). Rurality in England and Wales 1991: a replication and extension of the 1981 rurality index. Sociologia Ruralis, 38(2), 178-203.

Hugo, G., Champion, A., \& Lattes, A. (2003). Toward a new conceptualization of settlements for demography. Population and Development Review, 29(2), 277-297.

Ilbery, B. (1981). Dorset agriculture. A classification of regional types. Transactions of the Institute of British geographers 6, pp. 214-227 (WP 14)

Labrianidis, L. (2006). Human capital as the critical factor for the development of Europe's rural peripheral areas. The New European Rurality: Strategies for Small Firms, 41-59.

Leeuwen, E., (2015). Urban-Rural Synergies: An Explorative Study at the NUTS3 Level, Appl. Spatial Analysis, DOI 10.1007/S12061-0159167-X

Li, Y., Long, H., \& Liu, Y. (2015). Spatio-temporal pattern of China's rural development: A rurality index perspective. Journal of Rural Studies, 38, 12-26.

Long, H., Zou, J., \& Liu, Y. (2009). Differentiation of rural development driven by industrialization and urbanization in eastern coastal China. Habitat international, 33(4), 454-462.

Madu, I. A. (2010). The structure and pattern of rurality in Nigeria. GeoJournal, 75 (2), 175-184.

Malinen, P., Keränen, R., \& Keränen, H. (1994). Rural area typology in Finland: a tool for rural policy. Oulun yliopisto.

Michailidou, C., Maheras, P., Arseni-Papadimititriou, A., Kolyva-Machera, F., \& Anagnostopoulou, C. (2009). A study of weather types at Athens and Thessaloniki and their relationship to circulation types for the cold-wet period, part I: two-step cluster analysis. Theoretical and applied climatology, 97(1-2), 163-177.

Ocaña-Riola, R., \& Sánchez-Cantalejo, C. (2005). Rurality index for small areas in Spain. Social Indicators Research, 73(2), 247-266.

OECD, (1994). Creating Rural Indicators for Shaping Territorial Policy, OECD, Paris

OECD, (2011). Regional Typology Report. Directorate for Public Governance and Territorial Development. Our Urbanizing World, No:2014/3

Öğdül, H. G. (2010). Urban And Rural Definitions in Regional Context: A Case Study on Turkey. European Planning Studies, 18(9), 1519-1541

Pizzol, E. (2017). Rural Development Indicators for Regions with Different Degrees of «Rurality»: A Statistıcal Study.

Pizzoli, E., ve Gong, X. (2007). How to Best Classify Rural and Urban. in Ponencia Presentada En La Fourth International Conference on Agriculture Statistics (22-24).

Prieto-Lara, E., \& Ocaña-Riola, R. (2010). Updating rurality index for small areas in Spain. Social Indicators Research, 95(2), 267.

Punj, G., ve Stewart, D. W. (1983). Cluster Analysis in Marketing Research: Review and Suggestions for Application. Journal of Marketing Research, 20(2), 134-148.

Resmi Gazete, (2012). On Üđ̧ İlde Büyükşehir Belediyesi ve Yirmi Altı İlçe Kurulması İle Bazı Kanun ve Kanun Hükmünde Kararnamelerde Değişiklik Yapılmasına Dair Kanun

Satish, S. M., \& Bharadhwaj, S. (2010). Information search behaviour among new car buyers: A two-step cluster analysis. IIMB Management Review, 22(1-2), 5-15.

Scholz, J., \& Herrmann, S. (2010). Rural Regions İn Europe. A New Typology Showing The Diversity of European Rural Regions (No. 4). Discussion Paper.

Shih, M. Y., Jheng, J. W., \& Lai, L. F. (2010). A Two-Step Method For Clustering Mixed Categroical and Numeric Data. Tamkang Journal o Science and Engineering, 13(1), 11-19.

Sotte, F. (2003). An Evolutionary Approach to Rural Development. Some Lessons for The Policymaker, Associazione Alessandro Bartola, Collana Appunti, No. 3, Ancona, Italy.

Stefurak, T., Calhoun, G. B., \& Glaser, B. A. (2004). Personality typologies of male juvenile offenders using a cluster analysis of the Millon Adolescent Clinical Inventory introduction. International journal of offender therapy and comparative criminology, 48(1), 96-110.

Tatlıdil, H. (1992). Çok Değişkenli İstatistiksel Analiz. Ankara: Hacettepe Üniversitesi Yayınları

Tekin, B. (2018). Ward, K-Ortalamalar ve İki Adımlı Kümeleme Analizi Yöntemleri ile Finansal Göstergeler Temelinde Hisse Senedi Tercihi. Balıkesir Üniversitesi Sosyal Bilimler Enstitüsü Dergisi, 21(40), 401-436.

TÜBİTAK, (2014). Koruma Odaklı Kırsal Alan Planlaması: Bir Model Önerisi Projesi Final Raporu, Proje No: 108G173, Trabzon.

TÜİK, (2019). Bölgesel İstatistikler Veri Seti. https://biruni.tuik.gov.tr/bolgeselistatistik/ Erişim: Haziran, 2019.

UNECE, FAO, OECD, World Bank (2007) Rural Household's Livelihood And Well-Being: Statistics On Rural Development And Agriculture Household Income, Handbook, Geneva, Switzerland.

Vincze, M., \& Mezei, E. (2011). The İncrease of Rural Development Measures Efficiency at the Micro-Regions Level by Cluster Analysis. A Romanian Case Study. Eastern Journal of European Studies, 2(1), 13.

Wu, X., Zhan, F. B., Zhang, K., \& Deng, Q. (2016). Application of a twostep cluster analysis and the Apriori algorithm to classify the deformation states of two typical colluvial landslides in the Three Gorges, China. Environmental Earth Sciences, 75(2), 146. 